\title{
Pesquisa de casos envolvendo divórcios japoneses no Supremo Tribunal Federal: de 05.10.1988 até 22.08.2002
}

Claudia Lima Marques, Daniela Jacques e Maitê Schmitz (Grupo de Pesquisa CNPq "Mercosul e Direito do Consumidor"/UFRGS)

I. Decisões Monocráticas (23)

A) Homologação de Sentença: 18

B) Carta Rogatória: 04

C) Outros: 01

II. Acórdãos (07)

A) Homologação de Sentença: 06

B) Outros: 01

Total: 30

\section{I - Decisões Monocráticas}

\section{HOMOLOGAÇÃO DE SENTENÇA}

1) Classe / Origem

SE-7434 / JA

SENTENCA ESTRANGEIRA

Relator(a)

Min. MARCO AURÉLIO DJ DATA-01/08/2002 P - 0141

Julgamento

08/07/2002

${ }^{1}$ A fonte de pesquisa foi o site do Supremo Tribunal Federal: http://www.stf.gov.br 
Pesquisa de casos envolvendo divórcios japoneses no Supremo Tribunal Federal 177

\section{Despacho}

DECISÃO CERTIDÃO ADMINISTRATIVA DE DIVÓRCIO - EFICÁCIA DE SENTENÇA - HOMOLOGAÇÃO. 1. H. I. e S. I. solicitam, na peça de folhas 2 e 3, a homologação da certidão expedida pela autoridade administrativa de Ryuyou-cho, Iwatagun, Província de Shizuoka, Japão. O documento original foi anexado, em fotocópia autenticada, à folha 19, anverso e verso, dele constando, além da notícia do trânsitó em julgado da decisão, a chancela do consulado brasileiro. A tradução, feita por tradutor juramentado, encontra-se à folha 20 à 22. O parecer do Procurador-Geral da República, de folhas 35 e 36, é pelo deferimento do pedido. 2. É certo prever o artigo 102, inciso I, alínea "h", da Constituição Federal a competência do Supremo Tribunal Federal para processar e julgar, originariamente, a homologação das sentenças estrangeiras. Todavia há de adotar-se interpretação aditiva, vislumbrando-se, na referência a sentenças estrangeiras, documentos que, segundo a legislação de origem, tenham tal envergadura. É o caso do ato administrativo de divórcio. No Japão, o desenlace matrimonial não é alcançado via sentença, mas mediante o registro no cartório competente, atuando o administrador do distrito. Foi justamente o que ocorreu na espécie dos autos, conforme revela a peça de folha 19. O tema não é novo. Esta Corte, ao defrontar-se com o pedido de homologação da Sentença Estrangeira nำ1.282, originária da Noruega, proclamou, em acórdão redigido pelo ministro Mário Guimarães: Homologa-se o divórcio se foi feito com as formalidades de seu país de origem. Homologação de divórcio por decisão de autoridade administrativa. Efeitos, sendo um dos cônjuges de nacionalidade brasileira. Na oportunidade, em 30 de maio de 1952, pronunciaram- se os Ministros, a uma só voz, pela viabilidade da homologação, fazendo-o de forma fundamentada não só o relator, como também os ministros Abner de Vasconcelos, Luiz Gallotti e Orosimbo Nonato. Em 1953, o Plenário enfrentou situação na qual envolvido ato oriundo do Japão. Mais uma vez, proclamou: Homologa-se o divórcio amigável registrado, no Japão, pelo Prefeito Municipal - A lei desse país reconhece como legal o divórcio processado nessas condições (Sentença Estrangeira n⿳0 1.312). Funcionou como relator o ministro Mário Guimarães. Em 1967, voltou o Tribunal a examinar a matéria quanto ao que previsto na Dinamarca, procedendo novamente à homologação. Eis a ementa do acórdão: SENTENÇA ESTRANGEIRA DE DIVÓRCIO DE CIDADÃOS DINAMARQUESES. Homologação. Satisfeitas as exigências legais, é de ser homologada para todos os efeitos. A citada sentença decorrera de ato do próprio Rei da Dinamarca Sentença Estrangeira n ${ }^{1.943}$, relator ministro Adaucto Cardoso. Em 1975, veio a ser homologada a Sentença Estrangeira n².251, proveniente do Japão, sintetizando o ministro Moreira Alves a tese prevalecente: Divórcio. É homologável no Brasil divórcio por mútuo consentimento que, segundo o sistema jurídico japonês, se registra perante autoridade administrativa, independentemente de manifestação judicial. Precedente do S.T.F. Homologação com restrições, em face da nacionalidade brasileira de uma das partes. Seguiram-se homologações pela Presidência: Sentença Estrangeira nº 2.626-1/Bélgica, homologação em 26 de outubro de 1979, pelo Presidente ministro Antonio Neder; Sentença Estrangeira nº 2.891-3/Japão, homologação em 19 de março de 1981, pelo Presidente 
ministro Xavier de Albuquerque; Sentença Estrangeira n 3.298-8/Japão, homologação em 16 de setembro de 1983, pelo Presidente ministro Cordeiro Guerra. Em 19 de março de 1984, Sua Excelência homologou as Sentenças Estrangeiras, do Japão, de noํ 3.371 - 2 e 3.372-1, e o ministro Moreira Alves, na Presidência da Corte em. 2 de julho de 1986, homologou a de n 3.724-6, também originária do Japão. 3. Defiro o pedido formulado e homologo, para que surta eficácia no Brasil, o ato mediante o qual os requerentes divorciaram-se. 4. Expeça-se a carta de sentença. 5. Publique-se. Brasília, 8 de julho de 2002. Ministro MARCO AURÉLIO Presidente 3

2) Classe / Origem

SE-7047/JA

SENTENCA ESTRANGEIRA

Relator(a)

Min. MARCO AURÉLIO DJ DATA-01/08/2002 P - 0135

\section{Julgamento}

25/06/2002

Despacho

DECISÃO SENTENÇA DE DIVÓRCIO - ACORDO SOBRE BEM IMÓVEL EXISTENTE NO BRASIL - HOMOLOGAÇÃO. 1. S. A. R. e E. C. F. R., solicitam na peça de folha 2 a 4 , a homologação de sentença de divórcio proferida pelo Tribunal de Família de Utsunomiya, Japão, a qual incorporou acordo de separação e convenção de bens celebrado pelas partes. O documento original foi anexado às folhas 39 e 40, dele constando, além da notícia do trânsito em julgado da decisão, a chancela do consulado brasileiro, encontrando-se à folha 40 , o referido acordo. A tradução de ambos os documentos, feita por tradutor juramentado, está à folha 36 à 38 . O parecer do Procurador-Geral da República, de folhas 45 e 46, preconiza o deferimento do pedido, registrando: Sentença estrangeira de divórcio. Pedido conjunto. Disposições sobre guarda e sustento dos filhos do casal. Partilha de bem imóvel inexistente no Brasil obtida por acordo. Precedentes. Parecer pelo deferimento, por estarem presentes os requisitos legais e regimentais. Trata-se de pedido conjunto de homologação de sentença estrangeira de divórcio, prolatada pelo Tribunal de Família de Utsunomiya, Japão, a qual dispôs sobre a guarda e sustento dos filhos do casal, partilha de bens e outros acessórios, resultantes do acordo das partes, obtido por mediação do juízo processante. $O$ requerente, com a petição de fls. 34 , trouxe aos autos a certidão de divórcio, devidamente autenticada pela autoridade consular brasileira (fls. 40). A documentação apresentada atende os requisitos dos arts. 217 e 218 do Regimento Interno do Supremo Tribunal Federal. Está regularmente traduzida (fls. 36/37). O domicílio das partes, à época do divórcio, justifica a competência da justiça japonesa. O trânsito em 
Pesquisa de casos envolvendo divórcios japoneses no Supremo Tribunal Federal 179

julgado está comprovado a fls. 36, tradução. Nestas circunstâncias, opinamos favoravelmente à pretensão, ainda que a decisão tenha disposto sobre partilha de bem imóvel situado no Brasil, porquanto resultou de composição das partes, obtida por mediação no juízo alienígena. Nesse sentido as Sentenças Estrangeiras nos 3.888, 4.844 e 7.027.2. É de frisar que a regra concernente à competência exclusiva do Judiciário brasileiro para conhecer ações relativas a imóveis localizados no Brasil - artigos 12 da Lei de Introdução ao Código Civil e 89 do Código de Processo Civil - deve ser aplicada com a cabível cautela, já que a existência de conflito de interesses sobre o bem leva a uma conduta completamente diferente quando, no divórcio, as próprias partes chegam a um acordo, ultrapassando qualquer impasse. Assim, à luz da jurisprudência desta Corte, tratando-se de composição, não se aplica a regra alusiva à atuação única e exclusiva da autoridade judicante brasileira. Confira-se com os seguintes precedentes: Sentenças Estrangeiras no ${ }^{\circ}$ 3.633, 3.888, 4.844 e 3.408 e Sentença Estrangeira Contestada $n^{2} 4.512$. Na Sentença Estrangeira no 3.408, restou consignado: - HOMOLOGAÇÃO DE SENTENÇA ESTRANGEIRA. SEPARAÇÃO DE CÔNJUGES. PARTILHA DE BENS. E HOMOLOGÁVEL A SENTENÇA ESTRANGEIRA QUE HOMOLOGA ACORDO DE SEPARAÇÃO E DE PARTILHA DOS BENS DO CASAL, AINDA QUE SITUADOS NO BRASIL, PORTA QUE NÃO OFENDIDO O ART. 89 DO CPC, NA CONFORMIDADE DOS PRECEDENTES DO STF (RTJ. 90/11; 109/38; 112/1006). HOMOLOGAÇÃO DEFERIDA. A par do requerimento em conjunto de homologação da sentença de divórcio, tem-se a observância dos requisitos próprios. Homologo-a, para que surta, no território brasileiro, os efeitos pertinentes. 3. Expeça-se a carta de sentença. 4. Publiquese. Brasília, 25 de junho de 2002. Ministro MARCO AURÉLIO Presidente

\author{
3) Classe / Origem \\ SE-7410/JA \\ SENTENCA ESTRANGEIRA
}

Relator

Min. MARCO AURÉLIO DJ DATA-13/06/2002 P - 00039

\title{
Julgamento
}

06/06/2002 Despacho

DECISĀO

CERTIDÃO ADMINISTRATIVA DE DIVÓRCIO - EFICÁCIA DE SENTENÇA - HOMOLOGAÇÃO.

1. T. U. e E. K. U. solicitam, na peça de folhas 2 e 3 , a homologação da certidão expedida pela autoridade administrativa da cidade de Kawagoe, Província de Saitama, Koichi Funabashi, no Japão, bem como a alteração do nome da requerente. O documento original foi anexado em fotocópia autenticada à folha 15 , dele constando, além da notícia 
do trânsito em julgado da decisão, a chancela do consulado brasileiro. A tradução, feita por tradutor juramentado, encontra-se às folhas 16 e 17.

O parecer do Procurador-Geral da República, de folha 23, é pelo deferimento do pedido.

2. É certo prever o artigo 102, inciso I, alínea "h", da Constituição Federal a competência do Supremo Tribunal Federal para processar e julgar, originariamente, a homologação das sentenças estrangeiras. Todavia há de adotar-se interpretação aditiva, vislumbrando-se, na referência a sentenças estrangeiras, documentos que, segundo a legislação de origem, tenham tal envergadura. É o caso do ato administrativo de divórcio. No Japão, o desenlace matrimonial não é alcançado via sentença, mas mediante o registro no cartório competente, atuando o administrador do distrito. Foi justamente o que ocorreu na espécie dos autos, conforme revela a peça de folha 8.

O tema não é novo. Esta Corte, ao defrontar-se com o pedido de homologação da Sentença Estrangeira n⿳⼈ㅡㄹ 1.282, originária da Noruega, proclamou, em acórdão redigido pelo ministro Mário Guimarães:

Homologa-se o divórcio se foi feito com as formalidades de seu país de origem. Homologação de divórcio por decisão de autoridade administrativa. Efeitos, sendo um dos cônjuges de nacionalidade brasileira. Na oportunidade, em 30 de maio de 1952, pronunciaram-se os Ministros, a uma só voz, pela viabilidade da homologação, fazendoo de forma fundamentada não só o relator, como também os ministros Abner de Vasconcelos, Luiz Gallotti e Orosimbo Nonato. Em 1953, o Plenário enfrentou situaçăo na qual envolvido ato oriundo do Japão. Mais uma vez, proclamou: Homologa-se o divórcio amigável registrado, no Japão, pelo Prefeito Municipal - A lei desse país reconhece como legal o divórcio processado nessas condiçôes (Sentença Estrangeira no 1.312). Funcionou como relator o ministro Mário Guimarães. Em 1967,,-voltou o Tribunal a examinar a matéria quanto ao que previsto na Dinamarca, procedendo, novamente, à homologação. Eis a ementa do acórdão:

SENTENÇA ESTRANGEIRA DE DIVÓRCIO DE CIDADÃOS DINAMARQUESES. Homologação. Satisfeitas as exigências legais, é de ser homologada para todos os efeitos. A citada sentença decorrera de ato do próprio Rei da Dinamarca - Sentença Estrangeira n 1.943 , relator ministro Adaucto Cardoso. Em 1975, veio a ser homologada a Sentença Estrangeira n² 2.251, proveniente do Japão, sintetizando o ministro Moreira Alves a tese prevalecente: Divórcio. É homologável no Brasil divórcio por mútuo consentimento que, segundo o sistema jurídico japonês, se registra perante autoridade administrativa, independentemente de manifestação judicial. Precedente do S.T.F. Homologação com restrições, em face da nacionalidade brasileira de uma das partes.

Seguiram-se homologações pela Presidência: Sentença Estrangeira no 2.626-1/ Bélgica, homologação em 26 de outubro de 1979, pelo Presidente ministro Antonio Neder; Sentença Estrangeira no 2.891-3/Japão, homologação em 19 de março de 1981, pelo Presidente ministro Xavier de Albuquerque; Sentença Estrangeira no 3.298-8/Japão, 


\section{Pesquisa de casos envolvendo divórcios japoneses no Supremo Tribunal Federal 181}

homologação em 16 de setembro de 1983, pelo Presidente ministro Cordeiro Guerra. Em 19 de março de 1984, Sua Excelência homologou as Sentenças Estrangeiras, do Japão, de no 3.371-2 e 3.372-1, e o ministro Moreira Alves, na Presidência da Corte em 2 de julho de 1986, homologou a de n⿳⺈ 3.724-6, também originária do Japão.

3. A par do requerimento em conjunto de homologação de certidão de divórcio, tem-se o atendimento dos requisitos próprios. Quanto ao pedido de alteração de nome, de acordo com a jurisprudência desta Corte, a homologação deve se limitar aos termos estritos de seu conteúdo, não se admitindo a abrangência ou extensão a acordos, tópicos ou cláusulas não incorporados formalmente ao texto da decisão homologanda (Sentenças Estrangeiras $n{ }^{\circ}{ }_{s} 5.150,5.229$ e 5.405). A modificação de nome não compõe a certidão.

Homologo-a, com a ressalva apontada, para que produza, no território brasileiro, os efeitos cabíveis. 4. Expeça-se a carta de sentença. 5. Publique-se. Brasília, 6 de junho de 2002. Ministro MARCO AURÉLIO Presidente 3

4) Classe / Origem

SE-7122/JA

SENTENCA ESTRANGEIRA

Relator

Min. MARCO AURÉLIO DJ DATA-29/05/2002 P - 00038

\section{Julgamento}

22/05/2002 Despacho

DECISÃO

CERTIDÃO ADMINISTRATIVA DE DIVÓRCIO - EFICÁCIA DE SENTENÇA - HOMOLOGAÇÃO.

1. K. S. e S. S. solicitam, na peça de folhas 2 e 3, a homologação da certidão expedida pela autoridade administrativa de Tobata-Ku, Província Kitabyushu-Shi, no Japão. O documento original foi anexado às folhas 27 e 28, dele constando, além da notícia do trânsito em julgado da decisão, a chancela do consulado brasileiro. A tradução, feita por tradutor juramentado, encontra-se à folha 29 à 31.

O parecer do Procurador-Geral da República, de folha 36, é pelo deferimento do pedido.

2. É certo prever o artigo 102, inciso I, alínea "h", da Constituição Federal a competência do Supremo Tribunal Federal para processar e julgar, originariamente, a homologação das sentenças estrangeiras. Todavia, há de adotar-se interpretação aditiva, vislumbrando-se, na referência a sentenças estrangeiras, documentos que, segundo a legislação de origem, tenham tal envergadura. É o caso do ato administrativo de divórcio. No Japão, o desenlace matrimonial não é alcançado via sentença, mas mediante o registro no cartório competente, atuando o administrador do distrito. Foi justamente o que ocorreu 
na espécie dos autos, conforme revela a peça de folhas 27 e 28 . O tema não é novo. Esta Corte, ao defrontar-se com o pedido de homologação da Sentença Estrangeira no 1.282 , originária da Noruega, proclamou, em acórdão redigido pelo Ministro Mário Guimarães:

Homologa-se o divórcio se foi feito com as formalidades de seu país de origem. Homologação de divórcio por decisão de autoridade administrativa. Efeitos, sendo um dos cônjuges de nacionalidade brasileira. Na oportunidade, em 30 de maio de 1952 , pronunciaram-se os Ministros, a uma só voz, pela viabilidade da homologação, fazendoo de forma fundamentada não só o Relator, como também os Ministros Abner de Vasconcelos, Luiz Gallotti e Orosimbo Nonato. Em 1953, o Plenário veio a enfrentar situação na qual envolvido ato originário do Japão. Mais uma vez, proclamou-se:

Homologa-se o divórcio amigável registrado, no Japão, pelo Prefeito Municipal - A lei desse país reconhece como legal o divórcio processado nessas condições (Sentença Estrangeira ${ }^{\circ}$ 1.312). Funcionou como Relator o Ministro Mário Guimarães. Em 1967, voltou o Tribunal a examinar a matéria, fazendo-o quanto ao que previsto na Dinamarca. Mais uma vez, procedeu à homologação, assim ficando sintetizada a ementa do acórdão:

SENTENÇA ESTRANGEIRA DE DIVÓRCIO DE CIDADÃOS DINAMARQUESES. Homologação. Satisfeitas as exigências legais, é de ser homologada para todos os efeitos. A citada sentença decorrera de ato do próprio Rei da Dinamarca - Sentença Estrangeira nº 1.943, Relator Ministro Adaucto Cardoso. Em 1975, veio a ser homologada a Sentença Estrangeira nº 2.251, também originária do Japão, sintetizando o Ministro Moreira Alves a tese prevalecente:

Divórcio. É homologável no Brasil divórcio por mútuo consentimento que, segundo o sistema jurídico japonês, se registra perante autoridade administrativa, independentemente de manifestação judicial. Precedente do S.T.F. Homologação com restrições, em face da nacionalidade brasileira de uma das partes.

Seguiram-se homologações pela Presidência: Sentença Estrangeira no 2.626-1/ Bélgica, homologação em 26 de outubro de 1979, pelo Presidente Ministro Antonio Neder; Sentença Estrangeira no 2.891-3/Japão, homologação em 19 de março de 1981, pelo Presidente Ministro Xavier de Albuquerque; Sentença Estrangeira n 3.298-8/ Japão, homologação em 16 de setembro de 1983, pelo Presidente Ministro Cordeiro Guerra. Em 19 de março de 1984, Sua Excelência homologou as Sentenças Estrangeiras, originárias do Japão, de nºs 3.371-2 e 3.372-1, sendo que o Ministro Moreira Alves, na Presidência da Corte em 2 de julho de 1986, procedeu à homologação da de n⿳0 3.724-6, também originária do Japão.

3. Defiro o pedido formulado e homologo, para que surta eficácia no Brasil, o ato mediante o qual os requerentes

divorciaram-se.

4. Expeça-se a carta de sentença.

5. Publique-se.

Brasília, 22 de maio de 2002.

Ministro MARCO AURÉLIO 
Pesquisa de casos envolvendo divórcios japoneses no Supremo Tribunal Federal 183

Presidente

3

5) Classe / Origem

SE-6882/ JA

SENTENCA ESTRANGEIRA

\section{Relator}

Min. MARCO AURÉLIO DJ DATA-12/04/2002 P - 00078

\section{Julgamento}

04/04/2002 Despacho

DECISÃO

CERTIDÃO ADMINISTRATIVA DE DIVÓRCIO - EFICÁCIA DE SENTENÇA - HOMOLOGAÇÃO.

1. H. Y. C. solicita, na peça de folha 2 a 7, a homologação da certidão expedida por autoridade administrativa de Matsudo, Província de Shiba, no Japão. O documento original foi anexado às folhas 14 e 15, dele constando, além da notícia do trânsito em julgado da decisão, a chancela do consulado brasileiro. A tradução, feita por tradutor juramentado, encontra-se à folha 16 à 18 . Procedeu-se à citação do requerido por edital, conforme solicitado, e, decorrido o prazo para a contestação, nomeou-se curador especial o Dr. Moacir Antônio Machado da Silva que, na peça de folha 50, não se opôs à homologação.

O parecer do Procurador-Geral da República, de folha 61, é pelo deferimento do pedido.

2. É certo prever o artigo 102, inciso I, alínea "h", da Constituição Federal a competência do Supremo Tribunal Federal para processar e julgar, originariamente, a homologação das sentenças estrangeiras. Todavia, há de adotar-se interpretação aditiva, vislumbrando-se, na referência a sentenças estrangeiras, documentos que, segundo a legislação de origem, tenham tal envergadura. É o caso do ato administrativo de divórcio. No Japão, o desenlace matrimonial não é alcançado via sentença, mas mediante o registro no cartório competerte, atuando o administrador do distrito. Foi justamente o que ocorreu na espécie dos autos, conforme revela a peça de folhas 14 e 15 . O tema não é novo. Esta Corte, ao defrontar-se com o pedido de homologação da Sentença Estrangeira no ${ }^{\circ}$ 1.282, originária da Noruega, proclamou, em acórdão redigido pelo Ministro Mário Guimarães: Homologa-se o divórcio se foi feito com as formalidades de seu país de origem. Homologação de divórcio por decisão de autoridade administrativa. Efeitos, sendo um dos cônjuges de nacionalidade brasileira. Na oportunidade, em 30 de maio de 1952, pronunciaram-se os Ministros, a uma só voz, pela viabilidade da homologação, fazendo-o de forma fundamentada não só o Relator, como também os Ministros Abner de Vasconcelos, Luiz 
Gallotti e Orosimbo Nonato. Em 1953, o Plenário veio a enfrentar situação na qual envolvido ato originário do Japão. Mais uma vez, proclamou-se: Homologa-se o divórcio amigável registrado, no Japão, pelo Prefeito Municipal - A lei desse país reconhece como legal o divórcio processado nessas condições (Sentença Estrangeira nํㅜㄴ.312). Funcionou como Relator o Ministro Mário Guimarães. Em 1967, voltou o Tribunal a examinar a matéria, fazendo-o quanto ao que previsto na Dinamarca. Mais uma vez, procedeu à homologação, assim ficando sintetizada a ementa do acórdão:

SENTENÇA ESTRANGEIRA DE DIVÓRCIO DE CIDADÃOS DINAMARQUESES. Homologação. Satisfeitas as exigências legais, é de ser homologada para todos os efeitos. A citada sentença decorrera de ato do próprio Rei da Dinamarca - Sentença Estrangeira n 1.943, Relator Ministro Adaucto Cardoso. Em 1975, veio a ser homologada a Sentença Estrangeira nº 2.251, também originária do Japão, sintetizando o Ministro Moreira Alves a tese prevalecente:

Divórcio. É homologável no Brasil divórcio por mútuo consentimento que, segundo o sistema jurídico japonês, se registra perante autoridade administrativa, independentemente de manifestação judicial. Precedente do S.T.F. Homologação com restrições, em face da nacionalidade brasileira de uma das partes. Seguiram-se homologações pela Presidência: Sentença Estrangeira nº 2.626-1/Bélgica, homologação em 26 de outubro de 1979, pelo Presidente Ministro Antonio Neder; Sentença Estrangeira n 2.891-3/Japão, homologação em 19 de março de 1981, pelo Presidente Ministro Xavier de Albuquerque; Sentença Estrangeira no 3.298-8/Japão, homologação em 16 de setembro de 1983, pelo Presidente Ministro Cordeiro Guerra. Em 19 de março de 1984, Sua Excelência homologou as Sentenças Estrangeiras, originárias do Japão, de n⿳⺈⿴囗十一 3.371 -2 e 3.372-1, sendo que o Ministro Moreira Alves, na Presidência da Corte em 2 de julho de 1986, procedeu à homologação da de n⿳ㅜㅜ․724-6, também originária do Japão.

3. Defiro o pedido formulado e homologo, para que surta eficácia no Brasil, o ato mediante o qual a requerente divorciou-se.

4. Expeça-se a carta de sentença.

5. Publique-se.

Brasília, 4 de abril de 2002.

Ministro MARCO AURÉLIO

Presidente

6) Classe / Origem

SE-7039/JA

SENTENCA ESTRANGEIRA

Relator

Min. MARCO AURÉLIO DJ DATA-03/04/2002 P - 00054 


\section{Pesquisa de casos envolvendo divórcios japoneses no Supremo Tribunal Federal 185}

\section{Julgamento}

20/03/2002 Despacho

DECISÃO

\section{CERTIDÃO ADMINISTRATIVA DE DIVÓRCIO - EFICÁCIA DE SENTENÇA - HOMOLOGAÇÃO.}

1. O. S. e A. T. S. solicitam, na peça de folha 2 a 4, a homologação da certidão expedida por autoridade administrativa de Minori, Província de Ibaragi, no Japão. $\mathrm{O}$ documento original foi anexado à folha 66 à 71 , dele constando, além da notícia do trânsito em julgado da decisão, a chancela do consulado brasileiro. A tradução, feita por tradutor juramentado, encontra-se à folha 43 à 46 .

O parecer do Procurador-Geral da República, de folhas 84 e 85, é pelo deferimento do pedido.

2. É certo prever o artigo 102, inciso I, alínea " $h$ ", da Constituição Federal a competência do Supremo Tribunal Federal para processar e julgar, originariamente, a homologação das sentenças estrangeiras. Todavia, há de adotar-se interpretação aditiva, vislumbrando-se, na referência a sentenças estrangeiras, documentos que, segundo a legislação de origem, tenham tal envergadura. É o caso do ato administrativo de divórcio. No Japão, o desenlace matrimonial não é alcançado via sentença, mas mediante $o$ registro no cartório competente, atuando o administrador do distrito. Foi justamente o que ocorreu na espécie dos autos, conforme revela a peça de folha 43 a $46 . \mathrm{O}$ tema não é novo. Esta Corte, ao defrontar-se com o pedido de homologação da Sentença Estrangeira $\mathrm{n}^{\mathrm{o}} 1.282$, originária da Noruega, proclamou, em acórdão redigido pelo Ministro Mário Guimarães: Homologa-se o divórcio se foi feito com as formalidades de seu país de origem. Homologação de divórcio por decisão de autoridade administrativa. Efeitos, sendo um dos cônjuges de nacionalidade brasileira. $\mathrm{Na}$ oportunidade, em 30 de maio de 1952, pronunciaram-se os Ministros, a uma só voz, pela viabilidade da homologação, fazendo-o de forma fundamentada não só o Relator, como também os Ministros Abner de Vasconcelos, Luiz Gallotti e Orosimbo Nonato. Em 1953, o Plenário veio a enfrentar situação na qual envolvido ato originário do Japão. Mais uma vez, proclamou-se: Homologa-se o divórcio amigável registrado, no Japão, pelo Prefeito Municipal - A lei desse país reconhece como legal o divórcio processado nessas condições (Sentença Estrangeira n⿳⺈ 1.312). Funcionou como Relator o Ministro Mário Guimarães. Em 1967, voltou o Tribunal a examinar a matéria, fazendo-o quanto ao que previsto na Dinamarca. Mais uma vez, procedeu à homologação, assim ficando sintetizada a ementa do acórdão: SENTENÇA ESTRANGEIRA DE DIVÓRCIO DE CIDADÃOS DINAMARQUESES. Homologação. Satisfeitas as exigências legais, é de ser homologada para todos os efeitos. A citada sentença decorrera de ato do próprio Rei da Dinamarca - Sentença Estrangeira no 1.943, Relator Ministro Adaucto Cardoso. Em 1975, veio a ser homologada a Sentença Estrangeira no 2.251, também originária do Japão, sintetizando o Ministro Moreira Alves a tese prevalecente: Divórcio. É homologável no Brasil divórcio por mútuo consentimento que, segundo o sistema jurídico japonês, se 
registra perante autoridade administrativa, independentemente de manifestação judicial. Precedente do S.T.F. Homologação com restrições, em face da nacionalidade brasileira de uma das partes.

Seguiram-se homologações pela Presidência: Sentença Estrangeira nำ 2.626-1/ Bélgica, homologação em 26 de outubro de 1979, pelo Presidente Ministro Antonio Neder; Sentença Estrangeira n 2.891-3/Japão, homologação em 19 de março de 1981, pelo Presidente Ministro Xavier de Albuquerque; Sentença Estrangeira nํㅜ 3.298-8/ Japão, homologação em 16 de setembro de 1983, pelo Presidente Ministro Cordeiro Guerra. Em 19 de março de 1984, Sua Excelência homologou as Sentenças Estrangeiras, originárias do Japão, de n⿳⺈⿴囗十一 $3.371-2$ e 3.372-1, sendo que o Ministro Moreira Alves, na Presidência da Corte em 2 de julho de 1986, procedeu à homologação da de n⿳0 3.7246, também originária do Japão.

3. Defiro o pedido formulado e homologo, para que surta eficácia no Brasil, $o$ ato mediante o qual os requerentes

divorciaram-se.

4. Expeça-se a carta de sentença.

5. Publique-se.

Brasília, 20 de março de 2002.

Ministro MARCO AURÉLIO

Presidente

3

7) Classe / Origem

SE-7292/JA

SENTENCA ESTRANGEIRA

Relator

Min. MARCO AURÉLIO DJ DATA-15/03/2002 P - 00067

\section{Julgamento}

06/03/2002 Despacho

DECISÃO

SENTENÇA ESTRANGEIRA - DIVÓRCIO - HOMOLOGAÇÃO.

1. S. A. e M. T. T. A. solicitam, na peça de folha 2 a 5, a homologação de sentença de divórcio proferida pelo Tribunal de Família de Yokohama, no Japão. $\bigcirc$ documento original foi anexado à folha 19 , dele constando, além da notícia do trânsito em julgado da decisão, a chancela do consulado brasileiro. A tradução, feita por tradutor juramentado, encontra-se às folhas 17 e 18. O Procurador-Geral da República, no parecer de folha 32 , preconiza o deferimento do pedido. 
Pesquisa de casos envolvendo divórcios japoneses no Supremo Tribunal Federal 187

2. A par do requerimento em conjunto de homologação da sentença de divórcio, tem-se a observância dos requisitos próprios. Homologo-a, para que surta, no território brasileiro, os efeitos cabíveis.

3. Expeça-se a carta de sentença.

4. Publique-se.

Brasília, 6 de março de 2002.

Ministro MARCO AURÉLIO

Presidente

8) Classe / Origem

SE-7202 / JA

SENTENCA ESTRANGEIRA

\section{Relator}

Min. MARCO AURÉLIO DJ DATA-13/02/2002 P - 00012

\section{Julgamento}

01/02/2002 Despacho

DECISÃO

CERTIDÃO ADMINISTRATIVA DE DIVÓRCIO - EFICÁCIA DE SENTENÇA - HOMOLOGAÇÃO.

1. I. H. I. e S. G. solicitam, na peça de folhas 2 e 3, a homologação da certidão expedida pela autoridade administrativa de Yamato, Província de Kanagawa, no Japão. O documento original foi anexado à folha 10 , dele constando, além da notícia do trânsito em julgado da decisão, a chancela do consulado brasileiro. A tradução, feita por tradutor juramentado, encontra-se às folhas 11 e 12 . O parecer do ProcuradorGeral da República, de folha 17, é pelo deferimento do pedido com ressalva.

2. É certo prever o artigo 102, inciso I, alínea "h", da Constituição Federal a competência do Supremo Tribunal Federal para processar e julgar, originariamente, a homologação das sentenças estrangeiras. Todavia, há de adotar-se interpretação aditiva, vislumbrando-se, na referência a sentenças estrangeiras, documentos que, segundo a legislação de origem, tenham tal envergadura. É o caso do ato administrativo de divórcio. No Japão, o desenlace matrimonial não é alcançado via sentença, mas mediante o registro no cartório competente, atuando o administrador do distrito. Foi justamente o que ocorreu na espécie dos autos, conforme revela a peça de folha 10. O tema não é novo. Esta Corte, ao defrontar-se com o pedido de homologação da Sentença Estrangeira no 1.282, originária da Noruega, proclamou, em acórdão redigido pelo Ministro Mário Guimarães: Homologase o divórcio se foi feito com as formalidades de seu país de origem. Homologação de divórcio por decisão de autoridade administrativa. Efeitos, sendo um dos cônjuges de nacionalidade brasileira. 
Na oportunidade, em 30 de maio de 1952, pronunciaram- se os Ministros, a uma só voz, pela viabilidade da homologação, fazendo-o de forma fundamentada não só o Relator, como também os Ministros Abner de Vasconcelos, Luiz Gallotti e Orosimbo Nonato. Em 1953, o Plenário veio a enfrentar situação na qual envolvido ato originário do Japão. Mais uma vez, proclamou-se: Homologa-se o divórcio amigável registrado, no Japão, pelo Prefeito Municipal - A lei desse país reconhece como legal o divórcio processado nessas condições (Sentença Estrangeira n ${ }^{1}$ 1.312). Funcionou como Relator o Ministro Mário Guimarães. Em 1967, voltou o Tribunal a examinar a matéria, fazendo-o quanto ao que previsto na Dinamarca. Mais uma vez, procedeu à homologação, assim ficando sintetizada a ementa do acórdão: SENTENÇA ESTRANGEIRA DE DIVÓRCIO DE CIDADÃOS DINAMARQUESES. Homologação. Satisfeitas as exigências legais, é de ser homologada para todos os efeitos.

A citada sentença decorrera de ato do próprio Rei da Dinamarca - Sentença Estrangeira no 1.943, Relator Ministro Adaucto Cardoso. Em 1975, veio a ser homologada a Sentença Estrangeira n².251, também originária do Japão, sintetizando o Ministro Moreira Alves a tese prevalecente: Divórcio. É homologável no Brasil divórcio por mútuo consentimento que, segundo o sistema jurídico japonês, se registra perante autoridade administrativa, independentemente de manifestação judicial. Precedente do S.T.F. Homologação com restrições, em face da nacionalidade brasileira de uma das partes.

Seguiram-se homologações pela Presidência: Sentença Estrangeira nำ 2.626-1/ Bélgica, homologação em 26 de outubro de 1979, pelo Presidente Ministro Antonio Neder; Sentença Estrangeira n 2.891-3/Japão, homologação em 19 de março de 1981, pelo Presidente Ministro Xavier de Albuquerque; Sentença Estrangeira no 3.298-8/ Japão, homologação em 16 de setembro de 1983, pelo Presidente Ministro Cordeiro Guerra. Em 19 de março de 1984, Sua Excelência homologou as Sentenças Estrangeiras, originárias do Japão, de nos 3.371-2 e 3.372-1, sendo que o Ministro Moreira Alves, na Presidência da Corte em 2 de julho de 1986, procedeu à homologação da de no 3.724-6, também originária do Japão.

3. Defiro o pedido formulado e o homologo, com a restrição de que o ato mediante o qual os requerentes divorciaram-se somente produzirá efeitos plenos a partir de 5 de março de 2002 (artigo 226, $\S 6^{\circ}$, da Constituição Federal), observando-se, até essa data, o instituto da separação judicial.

4. Expeça-se a carta de sentença.

5. Publique-se.

Brasília, $1^{\circ}$ de fevereiro de 2002.

Ministro MARCO AURÉLIO

Presidente

3 
Pesquisa de casos envolvendo divórcios japoneses no Supremo Tribunal Federal 189

9) Classe / Origem

SE-7116/JA

SENTENCA ESTRANGEIRA

\section{Relator}

Min. MARCO AURÉLIO DJ DATA-07/02/2002 P - 00018

\section{Julgamento}

14/12/2001 Despacho

DECISÃO

\section{CERTIDÃO ADMINISTRATIVA DE DIVÓRCIO - EFICÁCIA DE SENTENÇA - HOMOLOGAÇÃO.}

1. E. M. I. solicita, na peça de folhas 2 e 3 , a homologação da certidão expedida por autoridade administrativa de Kakurakita, Cidade de Kitakyushu, no Japão. O documento original foi anexado à folha 18 , dele constando, além da notícia do trânsito em julgado da decisão, a chancela do consulado brasileiro. A tradução, feita por tradutor juramentado, encontra-se às folhas $16 \mathrm{e} 17$. O requerido, à folha 8 , declarou não se opor ao pleito. O parecer do Procurador-Geral da República, de folha 42, é pelo deferimento do pedido.

2. É certo prever o artigo 102, inciso I, alínea "h", da Constituição Federal a competência do Supremo Tribunal Federal para processar e julgar, originariamente, a homologação das sentenças estrangeiras. Todavia, há de adotar-se interpretação aditiva, vislumbrando-se, na referência a sentenças estrangeiras, documentos que, segundo a legislação de origem, tenham tal envergadura. É o caso do ato administrativo de divórcio. No Japão, o desenlace matrimonial não é alcançado via sentença, mas mediante o registro no cartório competente, atuando o administrador do distrito. Foi justamente o que ocorreu na espécie dos autos, conforme revela a peça de folha 18 . O tema não é novo. Esta Corte, ao defrontar-se com o pedido de homologação da Sentença Estrangeira no 1.282 , originária da Noruega, proclamou, em acórdão redigido pelo Ministro Mário Guimarães: Homologase o divórcio se foi feito com as formalidades de seu país de origem. Homologação de divórcio por decisão de autoridade administrativa. Efeitos, sendo um dos cônjuges de nacionalidade brasileira.

Na oportunidade, em 30 de maio de 1952, pronunciaram- se os Ministros, a uma só voz, pela viabilidade da homologação, fazendo-o de forma fundamentada não só o Relator, como também os Ministros Abner de Vasconcelos, Luiz Gallotti e Orosimbo Nonato. Em 1953, o Plenário veio a enfrentar situação na qual envolvido ato originário do Japão. Mais uma vez, proclamou-se: Homologa-se o divórcio amigável registrado, no Japão, pelo Prefeito Municipal - A lei desse país reconhece como legal o divórcio processado nessas condições (Sentença Estrangeira no 1.312). Funcionou como Relator o Ministro Mário Guimarães. Em 1967, voltou o Tribunal a examinar a matéria, fazendo-o quanto ao que previsto na Dinamarca. Mais uma vez, procedeu à homologação, assim ficando sintetizada a ementa do acórdão: SENTENÇA ESTRANGEIRA DE DIVÓRCIO DE CIDADÃOS 
DINAMARQUESES. Homologação. Satisfeitas as exigências legais, é de ser homologada para todos os efeitos.

A citada sentença decorrera de ato do próprio Rei da Dinamarca - Sentença Estrangeira $n^{\circ} 1.943$, Relator Ministro Adaucto Cardoso. Em 1975, veio a ser homologada a Sentença Estrangeira no 2.251, também originária do Japão, sintetizando o Ministro Moreira Alves a tese prevalecente: Divórcio. É homologável no Brasil divórcio por mútuo consentimento que, segundo o sistema jurídico japonês, se registra perante autoridade administrativa, independentemente de manifestação judicial. Precedente do S.T.F. Homologação com restrições, em face da nacionalidade brasileira de uma das partes.

Seguiram-se homologações pela Presidência: Sentença Estrangeira no 2.626-1/ Bélgica, homologação em 26 de outubro de 1979, pelo Presidente Ministro Antonio Neder; Sentença Estrangeira no 2.891-3/Japão, homologação em 19 de março de 1981, pelo Presidente Ministro Xavier de Albuquerque; Sentença Estrangeira no 3.298-8/ Japão, homologação em 16 de setembro de 1983, pelo Presidente Ministro Cordeiro Guerra. Em 19 de março de 1984, Sua Excelência homologou as Sentenças Estrangeiras, originárias do Japão, de n⿳ำ $3.371-2$ e 3.372-1, sendo que o Ministro Moreira Alves, na Presidência da Corte em 2 de julho de 1986, procedeu à homologação da de n⿳0 3.7246, também originária do Japão.

3. Defiro o pedido formulado e homologo, para que surta eficácia no Brasil, $\mathrm{o}$ ato mediante o qual a requerente divorciou-se.

4. Expeça-se a carta de sentença.

5. Publique-se.

Brasília, 14 de dezembro de 2001.

Ministro MARCO AURÉLIO

Presidente

3

10) Classe / Origem

SE-7188/JA

SENTENCA ESTRANGEIRA

Relator

Min. MARCO AURÉLIO DJ DATA-04/02/2002 P - 00147

\section{Julgamento}

18/12/2001 Despacho

DECISÃO

CERTIDÃO ADMINISTRATIVA DE DIVÓRCIO - EFICÁCIA DE SENTENÇA - HOMOLOGAÇÃO. 


\section{Pesquisa de casos envolvendo divórcios japoneses no Supremo Tribunal Federal 191}

1. A. L. B. C. e M. N. solicitam, na peça de folha 2 a 4, a homologação da certidão expedida pela autoridade administrativa da Cidade de Shobu, Município de Minami Saitama, Província de Saitama, no Japão. O documento original foi anexado à folha 8 , dele constando, além da notícia do trânsito em julgado da decisão, a chancela do consulado brasileiro. A tradução, feita por tradutor juramentado, encontra-se à folha 9 à 11 . $O$ parecer do Procurador-Geral da República, de folha 24, é pelo deferimento do pedido.

2. É certo prever o artigo 102, inciso I, alínea "h", da Constituição Federal a competência do Supremo Tribunal Federal para processar e julgar, originariamente, a homologação das sentenças estrangeiras. Todavia, há de adotar-se interpretação aditiva, vislumbrando-se, na referência a sentenças estrangeiras, documentos que, segundo a legislação de origem, tenham tal envergadura. É o caso do ato administrativo de divórcio. No Japão, o desenlace matrimonial não é alcançado via sentença, mas mediante o registro no cartório competente, atuando o administrador do distrito. Foi justamente o que ocorreu na espécie dos autos, conforme revela a peça de folha 8 . O tema não é novo. Esta Corte, ao defrontar-se com o pedido de homologação da Sentença Estrangeira nº 1.282, originária da Noruega, proclamou, em acórdão redigido pelo Ministro Mário Guimarães: Homologa-se o divórcio se foi feito com as formalidades de seu país de origem. Homologação de divórcio por decisão de autoridade administrativa. Efeitos, sendo um dos cônjuges de nacionalidade brasileira.

Na oportunidade, em 30 de maio de 1952, pronunciaram- se os Ministros, a uma só voz, pela viabilidade da homologação, fazendo-o de forma fundamentada não só o Relator, como também os Ministros Abner de Vasconcelos, Luiz Gallotti e Orosimbo Nonato. Em 1953, o Plenário veio a enfrentar situação na qual envolvido ato originário do Japão. Mais uma vez, proclamou-se: Homologa-se o divórcio amigável registrado, no Japão, pelo Prefeito Municipal - A lei desse país reconhece como legal o divórcio processado nessas condições (Sentença Estrangeira nำ1.312). Funcionou como Relator o Ministro Mário Guimarães. Em 1967, voltou o Tribunal a examinar a matéria, fazendo-o quanto ao que previsto na Dinamarca. Mais uma vez, procedeu à homologação, assim ficando sintetizada a ementa do acórdão: SENTENÇA ESTRANGEIRA DE DIVÓRCIO DE CIDADÃOS DINAMARQUESES. Homologação. Satisfeitas as exigências legais, é de ser homologada para todos os efeitos. A citada sentença decorrera de ato do próprio Rei da Dinamarca Sentença Estrangeira nº 1.943, Relator Ministro Adaucto Cardoso. Em 1975, veio a ser homologada a Sentença Estrangeira nº 2.251, também originária do Japão, sintetizando o Ministro Moreira Alves a tese prevalecente: Divórcio. É homologável no Brasil divórcio por mútuo consentimento que, segundo o sistema jurídico japonês, se registra perante autoridade administrativa, independentemente de manifestação judicial. Precedente do S.T.F. Homologação com restrições, em face da nacionalidade brasileira de uma das partes.

Seguiram-se homologações pela Presidência: Sentença Estrangeira nํ⒉626-1/ Bélgica, homologação em 26 de outubro de 1979, pelo Presidente Ministro Antonio Neder; Sentença Estrangeira no 2.891-3/Japão, homologação em 19 de março de 1981, pelo Presidente Ministro Xavier de Albuquerque; Sentença Estrangeira no 3.298-8/Japão, 
homologação em 16 de setembro de 1983, pelo Presidente Ministro Cordeiro Guerra. Em 19 de março de 1984, Sua Excelência homologou as Sentenças Estrangeiras, originárias do Japão, de nºs 3.371-2 e 3.372-1, sendo que o Ministro Moreira Alves, na Presidência da Corte em 2 de julho de 1986, procedeu à homologação da de nº 3.724-6, também originária do Japão.

3. Defiro o pedido formulado e homologo, para que surta eficácia no Brasil, $\mathrm{o}$ ato mediante o qual os requerentes divorciaram-se.

4. Expeça-se a carta de sentença.

5. Publique-se.

Brasília, 18 de dezembro de 2001.

Ministro MARCO AURÉLIO

Presidente

3

11) Classe / Origem

SE-7005 / JA

SENTENCA ESTRANGEIRA

\section{Relator}

Min. MARCO AURÉLIO DJ DATA-01/02/2002 P-00168

\section{Julgamento}

11/12/2001 Despacho

DECISÃO

CERTIDÃO ADMINISTRATIVA DE DIVÓRCIO - EFICÁCIA DE SENTENÇA - HOMOLOGAÇÃO.

1. C.S. H. solicita, na peça de folha 2 a 4 , a homologação da certidão expedida por autoridade administrativa do Bairro de Ritto, Município de Kurita, Província de Shiga, no Japão. $O$ documento original foi anexado à folha 17 , dele constando, além da notícia do trânsito em julgado da decisão, a chancela do consulado brasileiro. A tradução, feita por tradutor juramentado, encontra-se à folha 19 à 22 . O requerido, à folha 14 , declarou não se opor ao pleito. O parecer do Procurador-Geral da República, de folha 47, é pelo deferimento do pedido.

2. É certo prever o artigo 102, inciso I, alínea "h", da Constituição Federal a competência do Supremo Tribunal Federal para processar e julgar, originariamente, a homologação das sentenças estrangeiras. Todavia, há de adotar-se interpretação aditiva, vislumbrando-se, na referência a sentenças estrangeiras, documentos que, segundo a legislação de origem, tenham tal envergadura. É o caso do ato administrativo de divórcio. No Japão, o desenlace matrimonial não é alcançado via sentença, mas mediante o registro no cartório competente, atuando o administrador do distrito. Foi justamente o 


\section{Pesquisa de casos envolvendo divórcios japoneses no Supremo Tribunal Federal 193}

que ocorreu na espécie dos autos, conforme revela a peça de folha 17 . O tema não é novo. Esta Corte, ao defrontar-se com o pedido de homologação da Sentença Estrangeira nº 1.282, originária da Noruega, proclamou, em acórdão redigido pelo Ministro Mário Guimarães: Homologa-se o divórcio se foi feito com as formalidades de seu país de origem. Homologação de divórcio por decisão de autoridade administrativa. Efeitos, sendo um dos cônjuges de nacionalidade brasileira.

Na oportunidade, em 30 de maio de 1952, pronunciaram- se os Ministros, a uma só voz, pela viabilidade da homologação, fazendo-o de forma fundamentada não só o Relator, como também os Ministros Abner de Vasconcelos, Luiz Gallotti e Orosimbo Nonato. Em 1953, o Plenário veio a enfrentar situação na qual envolvido ato originário do Japão. Mais uma vez, proclamou-se: Homologa-se o divórcio amigável registrado, no Japão, pelo Prefeito Municipal - A lei desse país reconhece como legal o divórcio processado nessas condições (Sentença Estrangeira no 1.312).

Funcionou como Relator o Ministro Mário Guimarães. Em 1967, voltou o Tribunal a examinar a matéria, fazendo-o quanto ao que previsto na Dinamarca. Mais uma vez, procedeu à homologação, assim ficando sintetizada a ementa do acórdão: SENTENÇA ESTRANGEIRA DE DIVÓRCIO DE CIDADÃOS DINAMARQUESES. Homologação. Satisfeitas as exigências legais, é de ser homologada para todos os efeitos.

A citada sentença decorrera de ato do próprio Rei da Dinamarca - Sentença Estrangeira no 1.943, Relator Ministro Adaucto Cardoso. Em 1975, veio a ser homologada a Sentença Estrangeira n² 2.251, também originária do Japão, sintetizando o Ministro Moreira Alves a tese prevalecente: Divórcio. É homologável no Brasil divórcio por mútuo consentimento que, segundo o sistema jurídico japonês, se registra perante autoridade administrativa, independentemente de manifestação judicial. Precedente do S.T.F. Homologação com restrições, em face da nacionalidade brasileira de uma das partes. Seguiram-se homologações pela Presidência: Sentença Estrangeira nº 2.626-1/Bélgica, homologação em 26 de outubro de 1979, pelo Presidente Ministro Antonio Neder; Sentença Estrangeira nº 2.891-3/Japão, homologação em 19 de março de 1981, pelo Presidente Ministro Xavier de Albuquerque; Sentença Estrangeira n 3.298-8/Japão, homologação em 16 de setembro de 1983, pelo Presidente Ministro Cordeiro Guerra. Em 19 de março de 1984, Sua Excelência homologou as Sentenças Estrangeiras, originárias do Japão, de nº̄s 3.371-2 e 3.372-1, sendo que o Ministro Moreira Alves, na Presidência da Corte em 2 de julho de 1986, procedeu à homologação da de nº 3.724-6, também originária do Japão.

3. Defiro o pedido formulado e homologo, para que surta eficácia no Brasil, o ato mediante o qual a requerente divorciou-se.

4. Expeça-se a carta de sentença.

5. Publique-se.

Brasília, 11 de dezembro de 2001.

Ministro MARCO AURÉLIO

Presidente 
Observação

Alteração: 14/03/02, (SVF).

12) Classe / Origem

SE-6969 / JA

SENTENCA ESTRANGEIRA

\section{Relator}

Min. MARCO AURÉLIO DJ DATA-08/10/2001 P - 00011

Julgamento

21/09/2001 Despacho

DECISÃO

CERTIDÃO ADMINISTRATIVA DE DIVÓRCIO - EFICÁCIA DE SENTENÇA - HOMOLOGAÇÃO.

1. I. S. K. solicita, na peça de folha 2 a 4 , a homologação da certidão expedida por autoridade administrativa de Utsunomiya, no Japão. O documento original foi anexado à folha 8 , dele constando, além da notícia do trânsito em julgado da decisão, a chancela do consulado brasileiro. A tradução, feita por tradutor juramentado, encontra-se à folha 5 à 7 . O requerido, à folha 29 , declarou não se opor ao pleito. $\mathrm{O}$ Procurador-Geral da República emitiu o parecer de folha 33, preconizando o deferimento do pedido.

2. É certo prever o artigo 102, inciso I, alínea "h", da Constituição Federal a competência do Supremo Tribunal Federal para processar e julgar, originariamente, a homologação das sentenças estrangeiras. Todavia há de adotar-se interpretação aditiva, vislumbrando-se, na referência a sentenças estrangeiras, documentos que, segundo a legislação de origem, tenham tal envergadura. É o caso do ato administrativo de divórcio. No Japão, o desenlace matrimonial não é alcançado via sentença, mas mediante o registro no cartório competente, atuando o administrador do distrito. Foi justamente o que ocorreu na espécie dos autos, conforme revela a peça de folha 8 . O tema não é novo. Esta Corte, ao defrontar-se com o pedido de homologação da Sentença Estrangeira no 1.282 , originária da Noruega, proclamou, em acórdão redigido pelo Ministro Mário Guimarães: Homologase o divórcio se foi feito com as formalidades de seu país de origem. Homologação de divórcio por decisão de autoridade administrativa. Efeitos, sendo um dos cônjuges de nacionalidade brasileira.

Na oportunidade, em 30 de maio de 1952, pronunciaram-se os Ministros, a uma só voz, pela viabilidade da homologação, fazendo-o de forma fundamentada não só o Relator, como também os Ministros Abner de Vasconcelos, Luiz Gallotti e Orosimbo Nonato. Em 1953, o Plenário veio a enfrentar situação na qual envolvido ato originário do Japão. Mais uma vez, proclamou-se: Homologa-se o divórcio amigável registrado, no Japão, pelo Prefeito Municipal - A lei desse país reconhece como legal o divórcio processado nessas condições 
Pesquisa de casos envolvendo divórcios japoneses no Supremo Tribunal Federal 195

(Sentença Estrangeira no 1.312). Funcionou como Relator o Ministro Mário Guimarães. Em 1967, voltou o Tribunal a examinar a matéria, fazendo-o quanto ao que previsto na Dinamarca. Mais uma vez, procedeu à homologação, assim ficando sintetizada a ementa do acórdão: SENTENÇA ESTRANGEIRA DE DIVÓRCIO DE CIDADÃOS DINAMARQUESES. Homologação. Satisfeitas as exigências legais, é de ser homologada para todos os efeitos.

A citada sentença decorrera de ato do próprio Rei da Dinamarca - Sentença Estrangeira no 1.943, Relator Ministro Adaucto Cardoso. Em 1975, veio a ser homologada a Sentença Estrangeira no 2.251, também originária do Japão, sintetizando o Ministro Moreira Alves a tese prevalecente: Divórcio. É homologável no Brasil divórcio por mútuo consentimento que, segundo o sistema jurídico japonês, se registra perante autoridade administrativa, independentemente de manifestação judicial. Precedente do S.T.F. Homologação com restrições, em face da nacionalidade brasileira de uma das partes.

Seguiram-se homologações pela Presidência: Sentença Estrangeira n⿳0 2.626-1/ Bélgica, homologação em 26 de outubro de 1979, pelo Presidente Ministro Antonio Neder; Sentença Estrangeira no 2.891-3/Japão, homologação em 19 de março de 1981, pelo Presidente Ministro Xavier de Albuquerque; Sentença Estrangeira no 3.298-8/ Japão, homologação em 16 de setembro de 1983, pelo Presidente Ministro Cordeiro Guerra. Em 19 de março de 1984, Sua Excelência homologou as Sentenças Estrangeiras, originárias do Japão, de n⿳⺈ s.371-2 e 3.372-1, sendo que o Ministro Moreira Alves, na Presidência da Corte em 2 de julho de 1986, procedeu à homologação da de no 3.724-6, também originária do Japão.

3. Defiro o pedido formulado e homologo, para que surta eficácia no Brasil, o ato mediante o qual a requerente divorciou-se.

4. Expeça-se a carta de sentença.

5. Publique-se.

Brasília, 21 de setembro de 2001.

Ministro MARCO AURÉLIO

Presidente

13) Classe / Origem

SE-6878/JA

SENTENCA ESTRANGEIRA

Relator

Min. MARCO AURÉLIO DJ DATA-01/10/2001 P - 00012

\section{Julgamento}

13/09/2001 Despacho

DECISÃO 


\section{CERTIDÃO ADMINISTRATIVA DE DIVÓRCIO - EFICÁCIA DE SENTENÇA - HOMOLOGAÇÃO.}

1. A. Y. Y. solicita, na peça de folhas 2 e 3, a homologação da certidão expedida por autoridade administrativa de TSURUMI-KV, YOKOHAMA-SHI, no Japão. O documento original foi anexado à folha 14 , dele constando, além da notícia do trânsito em julgado da decisão, a chancela do consulado brasileiro. A tradução, feita por tradutor juramentado, encontra-se à folha 11 à 13 . O requerido, à folha 18 , declarou não se opor ao pleito. O Procurador-Geral da República emitiu o parecer de folha 27, preconizando o deferimento do pedido.

2. É certo prever o artigo 102, inciso I, alínea " $h$ ", da Constituição Federal a competência do Supremo Tribunal Federal para processar e julgar, originariamente, a homologação das sentenças estrangeiras. Todavia há de adotar-se interpretação aditiva, vislumbrando-se, na referência a sentenças estrangeiras, documentos que, segundo a legislação de origem, tenham tal envergadura. É o caso do ato administrativo de divórcio. No Japão, o desenlace matrimonial não é alcançado via sentença, mas mediante o registro no cartório competente, atuando o administrador do distrito. Foi justamente o que ocorreu na espécie dos autos, conforme revela a peça de folha 14 . O tema não é novo. Esta Corte, ao defrontar-se com o pedido de homologação da Sentença Estrangeira n 1.282 , originária da Noruega, proclamou, em acórdão redigido pelo Ministro Mário Guimarães: Homologa-se o divórcio se foi feito com as formalidades de seu país de origem. Homologação de divórcio por decisão de autoridade administrativa. Efeitos, sendo um dos cônjuges de nacionalidade brasileira. Na oportunidade, em 30 de maio de 1952, pronunciaram-se os Ministros, a uma só voz, pela viabilidade da homologação, fazendoo de forma fundamentada não só o Relator, como também os Ministros Abner de Vasconcelos, Luiz Gallotti e Orosimbo Nonato. Em 1953, o Plenário veio a enfrentar situação na qual envolvido ato originário do Japão. Mais uma vez, proclamou-se:

Homologa-se o divórcio amigável registrado, no Japão, pelo Prefeito Municipal - A lei desse país reconhece como legal o divórcio processado nessas condições (Sentença Estrangeira n 1.312). Funcionou como Relator o Ministro Mário Guimarães. Em 1967, voltou o Tribunal a examinar a matéria, fazendo-o quanto ao que previsto na Dinamarca. Mais uma vez, procedeu à homologação, assim ficando sintetizada a ementa do acórdão: SENTENÇA ESTRANGEIRA DE DIVÓRCIO DE CIDADÃOS DINAMARQUESES. Homologação. Satisfeitas as exigências legais, é de ser homologada para todos os efeitos. A citada sentença decorrera de ato do próprio Rei da Dinamarca - Sentença Estrangeira n⿳ำ 1.943, Relator Ministro Adaucto Cardoso. Em 1975, veio a ser homologada a Sentença Estrangeira $n^{\circ}$ 2.251, também originária do Japão, sintetizando o Ministro Moreira Alves a tese prevalecente: Divórcio. É homologável no Brasil divórcio por mútuo consentimento que, segundo o sistema jurídico japonês, se registra perante autoridade administrativa, independentemente de manifestação judicial. Precedente do S.T.F. Homologação com restrições, em face da nacionalidade brasileira de uma das partes. 
Seguiram-se homologações pela Presidência: Sentença Estrangeira nº 2.626-1/ Bélgica, homologação em 26 de outubro de 1979, pelo Presidente Ministro Antonio Neder; Sentença Estrangeira no 2.891-3/Japão, homologação em 19 de março de 1981, pelo Presidente Ministro Xavier de Albuquerque; Sentença Estrangeira nº 3.298-8/ Japão, homologação em 16 de setembro de 1983, pelo Presidente Ministro Cordeiro Guerra. Em 19 de março de 1984, Sua Excelência homologou as Sentenças Estrangeiras, originárias do Japão, de nº 3.371-2 e 3.372-1, sendo que o Ministro Moreira Alves, na Presidência da Corte em 2 de julho de 1986, procedeu à homologação da de n 3.724 6 , também originária do Japão.

3. Defiro o pedido formulado e homologo, para que surta eficácia no Brasil, $o$ ato mediante o qual a requerente divorciou-se.

4. Expeça-se a carta de sentença.

5. Publique-se.

Brasília, 13 de setembro de 2001.

Ministro MARCO AURÉLIO

Presidente

14) Classe / Origem

SE-6527 / JA

SENTENCA ESTRANGEIRA

\section{Relator}

Min. MARCO AURÉLIO DJ DATA-01/10/2001 P - 00011

\section{Julgamento}

13/09/2001 Despacho

DECISÃO

CERTIDÃO ADMINISTRATIVA DE DIVÓRCIO - EFICÁCIA DE SENTENÇA - HOMOLOGAÇÃO.

1. F. E. S. solicita, na peça de folhas 2 e 3 , a homologação da certidão expedida por autoridade administrativa de Ryozen, no Japão. $O$ documento original foi anexado à folha 58 à 60 , dele constando, além da notícia do trânsito em julgado da decisão, a chancela do consulado brasileiro. A tradução, feita por tradutor juramentado, encontra-se às folhas 32 e 33. Procedeu-se à citação do requerido por edital, conforme solicitado, e, decorrido o prazo para a contestação, nomeou-se curador especial o Dr. Márcio P. P. Garcia que, na peça de folha 51 , não se opôs à homologação. O ProcuradorGeral da República emitiu o parecer de folhas 71 e 72, preconizando o deferimento do pedido.

2. É certo prever o artigo 102, inciso I, alínea "h", da Constituição Federal a competência do Supremo Tribunal Federal para processar e julgar, originariamente, a 
homologação das sentenças estrangeiras. Todavia há de adotar-se interpretação aditiva, vislumbrando-se, na referência a sentenças estrangeiras, documentos que, segundo a legislação de origem, tenham tal envergadura. É o caso do ato administrativo de divórcio. No Japão, o desenlace matrimonial não é alcançado via sentença, mas mediante o registro no cartório competente, atuando o administrador do distrito. Foi justamente o que ocorreu na espécie dos autos, conforme revela a peça de folha 58 a 60 . O tema não é novo. Esta Corte, ao defrontar-se com o pedido de homologação da Sentença Estrangeira nº 1.282, originária da Noruega, proclamou, em acórdão redigido pelo Ministro Mário Guimarães: Homologa-se o divórcio se foi feito com as formalidades de seu país de origem. Homologação de divórcio por decisão de autoridade administrativa. Efeitos, sendo um dos cônjuges de nacionalidade brasileira.

Na oportunidade, em 30 de maio de 1952, pronunciaram-se os Ministros, a uma só voz, pela viabilidade da homologação, fazendo-o de forma fundamentada não só o Relator, como também os Ministros Abner de Vasconcelos, Luiz Gallotti e Orosimbo Nonato. Em 1953, o Plenário veio a enfrentar situação na qual envolvido ato originário do Japão. Mais uma vez, proclamou-se: Homologa-se o divórcio amigável registrado, no Japão, pelo Prefeito Municipal - A lei desse país reconhece como legal o divórcio processado nessas condições (Sentença Estrangeira nำ1.312).

Funcionou como Relator o Ministro Mário Guimarães. Em 1967, voltou o Tribunal a examinar a matéria, fazendo-o quanto ao que previsto na Dinamarca. Mais uma vez, procedeu à homologação, assim ficando sintetizada a ementa do acórdão: SENTENÇA ESTRANGEIRA DE DIVÓRCIO DE CIDADÃOS DINAMARQUESES. Homologação. Satisfeitas as exigências legais, é de ser homologada para todos os efeitos.

A citada sentença decorrera de ato do próprio Rei da Dinamarca - Sentença Estrangeira $\mathrm{n}^{\mathrm{o}}$ 1.943, Relator Ministro Adaucto Cardoso. Em 1975, veio a ser homologada a Sentença Estrangeira no 2.251, também originária do Japão, sintetizando o Ministro Moreira Alves a tese prevalecente: Divórcio. É homologável no Brasil divórcio por mútuo consentimento que, segundo o sistema jurídico japonês, se registra perante autoridade administrativa, independentemente de manifestação judicial. Precedente do S.T.F. Homologação com restrições, em face da nacionalidade brasileira de uma das partes.

Seguiram-se homologações pela Presidência: Sentença Estrangeira nำ 2.626-1/ Bélgica, homologação em 26 de outubro de 1979, pelo Presidente Ministro Antonio Neder; Sentença Estrangeira no 2.891-3/Japão, homologação em 19 de março de 1981, pelo Presidente Ministro Xavier de Albuquerque; Sentença Estrangeira no 3.298-8/ Japão, homologação em 16 de setembro de 1983, pelo Presidente Ministro Cordeiro Guerra. Em 19 de março de 1984, Sua Excelência homologou as Sentenças Estrangeiras, originárias do Japão, de $n^{\circ}$ s 3.371-2 e 3.372-1, sendo que o Ministro Moreira Alves, na Presidência da Corte em 2 de julho de 1986, procedeu à homologação da de no 3.724-6, também originária do Japão.

3. Defiro o pedido formulado e homologo, para que surta eficácia no Brasil, o ato mediante o qual a requerente divorciou-se. 
Pesquisa de casos envolvendo divórcios japoneses no Supremo Tribunal Federal 199

4. Expeça-se a carta de sentença.

5. Publique-se.

Brasília, 13 de setembro de 2001.

Ministro MARCO AURÉLIO

Presidente

3

15) Classe / Origem

SE-6607/JA

SENTENCA ESTRANGEIRA

\section{Relator}

Min. MARCO AURÉLIO DJ DATA-21/09/2001 P - 00061

\section{Julgamento}

06/09/2001 Despacho

DECISÃO

CERTIDÃO ADMINISTRATIVA DE DIVÓRCIO - EFICÁCIA DE SENTENÇA - HOMOLOGAÇÃO.

1. R. L. A. T. e T. T. solicitam, na peça de folha 2, a homologação da certidão expedida pela autoridade administrativa do Bairro de Nakano, no Japão. O documento original foi anexado à folha 48 à 51 , dele constando, além da notícia do trânsito em julgado da decisão, a chancela do consulado brasileiro. A tradução, feita por tradutor juramentado, encontra-se à folha 44 à 47. O Procurador-Geral da República emitiu o parecer de folha 56 , preconizando o deferimento do pedido.

2. É certo prever o artigo 102, inciso I, alínea "h", da Constituição Federal a competência do Supremo Tribunal Federal para processar e julgar, originariamente, a homologação das sentenças estrangeiras. Todavia, há de adotar-se interpretação aditiva, vislumbrando-se, na referência a sentenças estrangeiras, documentos que, segundo a legislação de origem, tenham tal envergadura. É o caso do ato administrativo de divórcio. No Japão, o desenlace matrimonial não é alcançado via sentença, mas mediante o registro no cartório competente, atuando o administrador do distrito. Foi justamente o que ocorreu na espécie dos autos, conforme revela a peça de folha 48 a 51 . O tema não é novo. Esta Corte, ao defrontar-se com o pedido de homologação da Sentença Estrangeira $\mathrm{n}$ @ 1.282, originária da Noruega, proclamou, em acórdão redigido pelo Ministro Mário Guimarães: Homologa-se o divórcio se foi feito com as formalidades de seu país de origem. Homologação de divórcio por decisão de autoridade administrativa. Efeitos, sendo um dos cônjuges de nacionalidade brasileira.

Na oportunidade, em 30 de maio de 1952, pronunciaram- se os Ministros, a uma só voz, pela viabilidade da homologação, fazendo-o de forma fundamentada não só o Relator, 
como também os Ministros Abner de Vasconcelos, Luiz Gallotti e Orosimbo Nonato. Em 1953, o Plenário veio a enfrentar situação na qual envolvido ato originário do Japão. Mais uma vez, proclamou-se: Homologa-se o divórcio amigável registrado, no Japão, pelo Prefeito Municipal - A lei desse país reconhece como legal o divórcio processado nessas condições (Sentença Estrangeira nำ1.312).

Funcionou como Relator o Ministro Mário Guimarães. Em 1967, voltou o Tribunal a examinar a matéria, fazendo-o quanto ao que previsto na Dinamarca. Mais uma vez, procedeu à homologação, assim ficando sintetizada a ementa do acórdão: SENTENÇA ESTRANGEIRA DE DIVÓRCIO DE CIDADÃOS DINAMARQUESES. Homologação. Satisfeitas as exigências legais, é de ser homologada para todos os efeitos.

A citada sentença decorrera de ato do próprio Rei da Dinamarca - Sentença Estrangeira $n^{2} 1.943$, Relator Ministro Adaucto Cardoso. Em 1975, veio a ser homologada a Sentença Estrangeira n 2.251, também originária do Japão, sintetizando o Ministro Moreira Alves a tese prevalecente: Divórcio. É homologável no Brasil divórcio por mútuo consentimento que, segundo o sistema jurídico japonês, se registra perante autoridade administrativa, independentemente de manifestação judicial. Precedente do S.T.F. Homologação com restrições, em face da nacionalidade brasileira de uma das partes.

Seguiram-se homologações pela Presidência: Sentença Estrangeira no 2.626-1/ Bélgica, homologação em 26 de outubro de 1979, pelo Presidente Ministro Antonio Neder; Sentença Estrangeira no 2.891-3/Japão, homologação em 19 de março de 1981, pelo Presidente Ministro Xavier de Albuquerque; Sentença Estrangeira no 3.298-8/ Japão, homologação em 16 de setembro de 1983, pelo Presidente Ministro Cordeiro Guerra. Em 19 de março de 1984, Sua Excelência homologou as Sentenças Estrangeiras, originárias do Japão, de nºs 3.371-2 e 3.372-1, sendo que o Ministro Moreira Alves, na Presidência da Corte em 2 de julho de 1986, procedeu à homologação da de no -3.724 6, também originária do Japão.

Defiro o pedido formulado e homologo, para que surta eficácia no Brasil, o ato mediante o qual os requerentes divorciaram-se.

3. Expeça-se a carta de sentença.

4. Publique-se.

Brasília, 6 de setembro de 2001.

Ministro MARCO AURÉLIO

Presidente

16) Classe / Origem

SE-6848/JA

SENTENCA ESTRANGEIRA 
Pesquisa de casos envolvendo divórcios japoneses no Supremo Tribunal Federal 201

\section{Relator}

Min. MARCO AURÉLIO DJ DATA-06/09/2001 P - 00030

\section{Julgamento}

28/08/2001 Despacho

DECISÃO

\section{CERTIDÃO ADMINISTRATIVA DE DIVÓRCIO - EFICÁCIA DE SENTENÇA - HOMOLOGAÇÃO.}

1. S. K. e H. H. K. solicitam, na peça de folha 2, a homologação da certidão expedida pela autoridade administrativa de Matsue, Província de Shimane, no Japão. O documento original foi anexado à folha 25 , dele constando, além da notícia do trânsito em julgado da decisão, a chancela do consulado brasileiro. A tradução, feita por tradutor juramentado, encontra-se às folhas $13,14,16$ e 17. O Procurador-Geral da República emitiu o parecer de folha 36 , preconizando o deferimento do pedido.

2. É certo prever o artigo 102, inciso I, alínea "h", da Constituição Federal a competência do Supremo Tribunal Federal para processar e julgar, originariamente, a homologação das sentenças estrangeiras. Todavia há de adotar-se interpretação aditiva, vislumbrando-se, na referência a sentenças estrangeiras, documentos que, segundo a legislação de origem, tenham essa envergadura. É o caso do ato administrativo de divórcio. No Japão, o desenlace matrimonial não é alcançado via sentença, mas mediante o registro no cartório competente, atuando o administrador do distrito. Foi justamente o que ocorreu na espécie dos autos, conforme revela a peça de folha 25.0 tema não é novo. Esta Corte, ao defrontar-se com o pedido de homologação da Sentença Estrangeira no 1.282 , originária da Noruega, proclamou, em acórdão redigido pelo Ministro Mário Guimarães: Homologa-se o divórcio se foi feito com as formalidades de seu país de origem. Homologação de divórcio por decisão de autoridade administrativa. Efeitos, sendo um dos cônjuges de nacionalidade brasileira.

Na oportunidade, em 30 de maio de 1952, pronunciaram- se os Ministros, a uma só voz, pela viabilidade da homologação, fazendo-o de forma fundamentada não só o Relator, como também os Ministros Abner de Vasconcelos, Luiz Gallotti e Orosimbo Nonato. Em 1953, o Plenário veio a enfrentar situação na qual envolvido ato originário do Japão. Novamente, deliberou-se: Homologa-se o divórcio amigável registrado, no Japão, pelo Prefeito Municipal - A lei desse país reconhece como legal o divórcio processado nessas condições (Sentença Estrangeira n⿳0 1.312).

Funcionou como Relator, na hipótese, o Ministro Mário Guimarães. Em 1967, voltou o Tribunal a examinar a matéria, dessa vez em relação ao que previsto na Dinamarca, procedendo-se também à homologação, assim ficando sintetizada a ementa do acórdão: SENTENÇA ESTRANGEIRA DE DIVÓRCIO DE CIDADÃOS DINAMARQUESES. Homologação. Satisfeitas as exigências legais, é de ser homologada para todos os efeitos.

A citada sentença decorrera de ato do próprio Rei da Dinamarca - Sentença Estrangeira nº 1.943, Relator Ministro Adaucto Cardoso. Em 1975, homologou-se a Sentença 
Estrangeira n 2.251, também originária do Japão, sintetizando o Ministro Moreira Alves a tese prevalecente: Divórcio. É homologável no Brasil divórcio por mútuo consentimento que, segundo o sistema jurídico japonês, se registra perante autoridade administrativa, independentemente de manifestação judicial. Precedente do S.T.F. Homologação com restrições, em face da nacionalidade brasileira de uma das partes.

Seguiram-se homologações pela Presidência: Sentença Estrangeira no 2.626-1/ Bélgica, homologação em 26 de outubro de 1979, pelo Presidente Ministro Antonio Neder; Sentença Estrangeira n 2.891-3/Japão, homologação em 19 de março de 1981, pelo Presidente Ministro Xavier de Albuquerque; Sentença Estrangeira no 3.298-8/Japão, homologação em 16 de setembro de 1983, pelo Presidente Ministro Cordeiro Guerra. Em 19 de março de 1984, Sua Excelência homologou as Sentenças Estrangeiras, originárias do Japão, de nºs 3.371-2 e 3.372-1, sendo que o Ministro Moreira Alves, na Presidência da Corte em 2 de julho de 1986, procedeu à homologação da de nº 3.724-6, também originária do Japão.

Defiro o pedido formulado e homologo, para que surta eficácia no Brasil, o ato mediante o qual os requerentes divorciaram-se.

3. Expeça-se a carta de sentença.

4. Publique-se.

Brasília, 28 de agosto de 2001.

Ministro MARCO AURÉLIO

Presidente

17) Classe / Origem

SE-5608/JA

SENTENCA ESTRANGEIRA

\section{Relator}

Min. CELSO DE MELLO DJ DATA-25-11-97 P-61400

\section{Julgamento}

18/11/1997 Despacho

Sentença estrangeira de divórcio.

Citação por edital. Requisitos atendidos. Deferimento. V. G. S. ou V. G. M., brasileira, requer a homologação de sentença estrangeira de divórcio que foi proferida, em 25 de agosto de 1995, segundo as leis do país de origem. O requerido, citado por edital, não se manifestou nos autos, sendo-lhe nomeado curador especial o Dr. J. G. V., que se pronunciou pela homologação (fls. 30/35). Atendidos os requisitos previstos no art. 217 e no art. 218 do Regimento Interno do Supremo Tribunal Federal, e não se configurando qualquer das restrições inscritas no art. 216 do RISTF, homologo, nos termos 
Pesquisa de casos envolvendo divórcios japoneses no Supremo Tribunal Federal 203

do parecer do Ministério Público Federal, a sentença estrangeira em referência, para que produza, no território brasileiro, os seus regulares efeitos legais.

Expeça-se a respectiva carta de sentença.

Publique-se.

Brasília, 18 de novembro de 1997.

Ministro CELSO DEMELLO

Presidente

Observação

Resultado : Homologada.

N.PP.:(01). Análise:(). Revisão:(AAF).

Inclusão: 21/10/98, (SVF).

Alteração: 02/08/00, (SVF).

Indexação EDITAL,

IN0041, SENTENÇA ESTRANGEIRA, DIVORCIO, CITAÇÃO POR

\section{REQUISITOS, ATENDIMENTO}

Despachos no mesmo sentido

PROC-SE NUM-0005082 ANO-97 UF-EU MIN-155 N.PP-001

DJ DATA-17-11-97 P-*****

PROC-SE NUM-0004477 ANO-94 UF-TQ MIN-141 N.PP-001

DJ DATA-26-04-94 P-*****

PROC-SE NUM-0005316 ANO-97 UF-AT MIN-155 N.PP-001

DJ DATA-10-12-97 P-*****

PROC-SE NUM-0005513 ANO-98 UF-IN MIN-155 N.PP-001

DJ DATA-19-02-98 P-*****

PROC-SE NUM-0005490 ANO-98 UF-EU MIN-155 N.PP-001

DJ DATA-03-04-98 P-*****

18) Classe / Origem

SE-5125/JA

SENTENCA ESTRANGEIRA

Relator

Min. SEPULVEDA PERTENCE

\section{Julgamento}

23/11/1997 Despacho 
Divórcio consensual processado perante autoridade administrativa japonesa. Requisitos atendidos. Homologação deferida.

N. D., japonês, e I. O. D. ou I. O., brasileira, requerem a homologação de ato lavrado perante o Prefeito de Nakajima, Kashima, Província de Ishikawa, Japão, que dissolveu o casamento de ambos. O Ministério Público Federal manifestou-se pelo deferimento do pedido, verbis (f. 26/27):

"Trata o presente processo de pedido conjunto de homologação de divórcio consensual, processado perante o prefeito de Nakajima, Ishikawa, Japão. Os requerentes juntaram a respectiva certidão, autenticada pelo representante consular do Brasil em Tóquio (fls. 23-v), bem assim a correspondente tradução, feita por tradutor oficial em São Paulo (fls. 8/9). Respeitada a peculiaridade do procedimento, conforme a legislação japonesa aplicável à espécie, a peça homologanda equivale à sentença irrecorrível. Atendidas, assim, as exigências do art. 217 do RI, somos pelo deferimento da pretensão."

Assim sendo, homologo o divórcio de que se trata, para que produza efeitos no Brasil. Expeça-se a respectiva carta de sentença.

Brasília, 23 de novembro de 1995.

Ministro SEPULVEDA PERTENCE - Presidente.

Observação

Resultado: Deferida.

N.PP.:(1). Análise:(LMS). Revisão:(AAF).

Inclusão: 14/07/97, (LSS).

Legislação

LEG-FED RGI-****** ANO-1980

ART-00217

****** RISTF-80 REGIMENTO INTERNO DO SUPREMO TRIBUNAL FEDERAL

Indexação

IN0041, SENTENÇA ESTRANGEIRA, DIVORCIO, AUTORIDADE ADMINISTRATIVA,

REQUISITOS, CUMPRIMENTO

Despachos no mesmo sentido

PROC-SE NUM-0005219 ANO-95 UF-JA MIN-154 N.PP-001

\section{CARTA ROGATÓRIA}

1) Classe / Origem

CR-9677/**

CARTA ROGATORIA 
Pesquisa de casos envolvendo divórcios japoneses no Supremo Tribunal Federal 205

\section{Relator \\ Min. MARCO AURÉLIO DJ DATA-03/04/2002 \\ Julgamento \\ Despacho \\ DECISÃO \\ DIREITO - ORGANICIDADEN E DINÂMICA.}

1. Por meio da decisão de folhas 51 e 52, o ministro Carlos Velloso, então Presidente da Corte, concedeu a execução do ato judicial. Ao fazê-lo, deixou consignado:

Trata-se de carta rogatória proveniente do Japão, que tem por finalidade a citação de T. M. M. bem como sua intimação para comparecimento em audiência no dia 06 de dezembro de 2002, conforme especificação no texto rogatório (fl. 4). Intimada, por via postal, insurge-se a requerida contra a concessão do exequatur ao apresentar a impugnação de fls. 38/42, com fundamento no art. 226, § 2o do R.I./S.T.F. Sustenta, em síntese, a requerida a afronta à soberania nacional e à ordem pública, ao argumento de que a ação de divórcio, que ora tramita na Justiça japonesa, não pode prosseguir, pois o casamento da requerida ocorreu no Brasil, em março de 1988 , sob a égide da lei brasileira, circunstância que impediria o pedido de divórcio em outro país. Por essas razões, "provado está que há afronta direta a nossa soberania e a nossa ordem pública; uma vez que a lei em tela é brasileira; e não a japonesa, como quer o Juízo Rogante fazer-se entender, impondo, destarte, o indeferimento do exequatur."(fl. 39) Pede, ainda, os benefícios da justiça gratuita. O Ministério Público Federal opina pela rejeição da impugnação e pela concessão do exequatur.

Autos conclusos em 19.03.2001.

Posto isso, decido.

Destaco do parecer da Procuradoria-Geral da República, lavrado pelo Dr. Miguel Frauzino Pereira, aprovado pelo Procurador-Geral da República, professor Geraldo Brindeiro:

“(...)A presente rogatória visa à citação de pessoa residente em nosso país, bem como a sua intimação para o comparecimento em audiência no dia 06 de dezembro de 2002 (fls.04). Intimada previamente, por via postal, insurge-se a requerida através da impugnação de fls.38/42, alegando ofensa à ordem pública e à soberania nacional, uma vez que o casamento, objeto do pedido de divórcio ajuizado na justiça alienígena, foi celebrado em nosso território. A irresignação não merece prosperar. Trata-se, no presente caso, de hipótese em que a competência da justiça brasileira é concorrente, nos termos do art. 88 do CPC. Ainda, a diligência rogada não ofende a ordem pública, nem a soberania nacional, uma vez que se traduz, apenas, em cientificar a requerida quanto à existência de ação em curso perante a justiça alienígena, onde poderão ser argüidas as exceções cabíveis. Opinamos, assim, pela rejeição da impugnação e pela concessão do exequatur. (...)". (fls. 46/47)

Correto o parecer, que adoto. Em conseqüência, concedo o exequatur. 
Publique-se.

À folha 53, foi certificada a ausência de recurso, baixando então os autos à $2^{\mathrm{a}}$ Vara Federal de Piracicaba para a execução, tendo ocorrido a citação em 9 de maio de 2001 (folha 57 - anverso e verso). Em 29 de maio imediato, a interessada protocolou a contestação de folha 62 a 65 , por meio da qual aponta a incompetência da autoridade judiciária do Japão, uma vez que o casamento ocorreu em território nacional, sob a égide da lei brasileira - incisos I e III do artigo 88 do Código de Processo Civil. Em passo seguinte, discorre sobre o término da relação conjugal, combatendo os argumentos que teriam sido apresentados pelo ex-cônjuge, e informa que propôs ação de divórcio litigioso na comarca de Piracicaba. Por fim, requer a improcedência do pedido e ressalta que, no caso de dissolução do casamento, o filho do casal deve ficar sob a guarda e responsabilidade materna.

2. O Direito, especialmente o instrumental, é orgânico e dinâmico, somente ficando viabilizada a volta a fase ultrapassada quando houver previsão legal. Conforme já consignado, refutou-se a impugnação da citanda à carta rogatória e, à execução determinada, não se seguiu agravo. A peça de folha 62 a 65 , apresentada sob a nomenclatura contestação, surge, assim, imprópria. Ainda que fosse considerada como embargos ao cumprimento da carta - o que não é possível, uma vez que o tema nela veiculado não diz com a execução em si, ocorrida no Juízo Federal, mas com a deliberação proveniente desta Corte -, seria intempestiva, porquanto protocolada somente em 29 de maio - fora, portanto, dos dez dias de que cuida o artigo 228 do Regimento Interno, tendo em vista que a citação deu-se em 9 de maio -, e distanciada do objeto da medida.

3. Por tais razões, deixo de examinar a matéria de fundo da referida peça.

4. Uma vez transcorrido o prazo para a impugnação desta decisão, devolva-se a carta à origem.

5. Publique-se.

Brasília, 19 de março de 2002.

Ministro MARCO AURÉLIO

Presidente

3

Partes

1.1) Classe / Origem

CR-9677/JA

CARTA ROGATORIA

Relator

Min. CARLOS VELLOSO DJ DATA-29/03/2001 P - 00007

Julgamento 


\section{Pesquisa de casos envolvendo divórcios japoneses no Supremo Tribunal Federal 207}

21/03/2001 Despacho

DECISÃO: - Vistos.

Trata-se de carta rogatória proveniente do Japão, que tem por finalidade a citação de T. M. M. bem como sua intimação para comparecimento em audiência no dia 06 de dezembro de 2002, conforme especificação no texto rogatório (fl. 4). Intimada, por via postal, insurge-se a requerida contra a concessão do exequatur ao apresentar a impugnação de fls. $38 / 42$, com fundamento no art. 226 , $\S 2$ ${ }^{\circ}$ do R.I./S.T.F. Sustenta, em síntese, a requerida a afronta à soberania nacional e à ordem pública, ao argumento de que a ação de divórcio, que ora tramita na Justiça japonesa, não pode prosseguir, pois o casamento da requerida ocorreu no Brasil, em março de 1988, sob a égide da lei brasileira, circunstância que impediria o pedido de divórcio em outro país. Por essas razões, "provado está que há afronta direta a nossa soberania e a nossa ordem pública; uma vez que a lei em tela é brasileira; e não a japonesa, como quer o Juízo Rogante fazer-se entender, impondo, destarte, o indeferimento do exequatur."(fl. 39) Pede, ainda, os benefícios da justiça gratuita. $O$ Ministério Público Federal opina pela rejeição da impugnação e pela concessão do exequatur.

Autos conclusos em 19.03.2001.

Posto isso, decido.

Destaco do parecer da Procuradoria-Geral da República, lavrado pelo Dr. Miguel Frauzino Pereira, aprovado pelo Procurador- Geral da República, professor Geraldo Brindeiro:

"(...)

A presente rogatória visa à citação de pessoa residente em nosso país, bem como a sua intimação para o comparecimento em audiência no dia 06 de dezembro de 2002 (fls.04). Intimada previamente, por via postal, insurge-se a requerida através da impugnação de fls.38/42, alegando ofensa à ordem pública e à soberania nacional, uma vez que o casamento, objeto do pedido de divórcio ajuizado na justiça alienígena, foi celebrado em nosso território. A irresignação não merece prosperar. Trata-se, no presente caso, de hipótese em que a competência da justiça brasileira é concorrente, nos termos do art. 88 do CPC. Ainda, a diligência rogada não ofende a ordem pública, nem a soberania nacional, uma vez que se traduz, apenas, em cientificar a requerida quanto à existência de ação em curso perante a justiça alienígena, onde poderão ser argüidas as exceções cabíveis. Opinamos, assim, pela rejeição da impugnação e pela concessão do exequatur. (...)". (fls. 46/47)

Correto o parecer, que adoto. Em conseqüência, concedo o exequatur.

Publique-se.

Brasília, 21 de março de 2001.

Ministro CARLOS VELLOSO

- Presidente - 
2) Classe / Origem

CR-10091/JA

CARTA ROGATORIA

Relator

Min. MARCO AURÉLIO DJ DATA-26/03/2002 P - 00040

\section{Julgamento}

18/03/2002 Despacho

DECISÃO

CARTA ROGATÓRIA - CITAÇĀO - CUMPRIMENTO.

1. Esta carta rogatória visa à citação de pessoa residente no Brasil.

2. A formalização do instrumento fez-se com observância dos requisitos próprios. O interessado, intimado, não ofereceu impugnação, e o Ministério Público pronunciou-se pela execução, além do que não está em questão ato contrário à soberania nacional ou à ordem pública.

3. Concedo a execução do objeto desta carta, a qual deve ser enviada à Justiça Federal no Estado de São Paulo, objetivando as providências cabíveis. Ressalto a necessidade de todo o empenho possível na localização do interessado.

4. Uma vez cumprida, devolva-se a esta Corte, para remessa, por via diplomática, à origem.

5. Publique-se.

Brasília, 18 de março de 2002.

Ministro MARCO AURÉLIO

Presidente

3) Classe / Origem

CR-9965 /JA

CARTA ROGATORIA

Relator

Min. MARCO AURÉLIO DJ DATA-18/02/2002 P - 00006

Julgamento

04/02/2002 Despacho

DECISÃO

CARTA ROGATÓRIA - CUMPRIMENTO.

1. Esta carta rogatória visa à intimação de pessoa residente no Brasil. 
2. A formalização do instrumento fez-se com observância dos requisitos próprios. A interessada, intimada, não ofereceu impugnação, e o Ministério Público pronunciou-se pela execução, além do que não está em questão ato contrário à soberania nacional ou à ordem pública.

3. Concedo a execução do objeto desta carta, a qual deve ser enviada à Justiça Federal no Estado de São Paulo, objetivando as providências cabíveis.

4. Uma vez cumprida, devolva-se a esta Corte, para remessa, por via diplomática, à origem.

5. Publique-se.

Brasília, 4 de fevereiro de 2002.

Ministro MARCO AURÉLIO

Presidente

4) Classe / Origem

CR-9772 / JA

CARTA ROGATORIA

Relator

Min. MARCO AURÉLIO DJ DATA-29/08/2001 P - 00017

\section{Julgamento}

07/08/2001 Despacho

DECISÃO

CARTA ROGATÓRIA - IMPUGNAÇÃO - IRREGULARIDADE DE REPRESENTAÇÃO PROCESSUAL. CARTA ROGATÓRIA - CUMPRIMENTO.

1. Trata-se de carta rogatória proveniente do Japão, com a finalidade de possibilitar, a M. O., vista de documentos do Processo n⿳9 483/96, do qual é parte. Feita a intimação do requerido, sobreveio a impugnação de folhas 33 e 34, na qual se manifesta estranheza pelo fato de a rogatória chegar às mãos do interessado via postal, acompanhada apenas de cópia dos artigos 225 a 229 do Regimento Interno do Supremo Tribunal Federal, "e não do mérito que lhe deu causa". O fato estaria a impedir a parte de apresentar defesa. Requer-se, assim, que sejam anexados ao ofício de intimação os documentos atinentes ao "mérito impugnável", abrindo-se, posteriormente, vistas e prazos para a impugnação. Protesta-se pela juntada de procuração em quinze dias. O ProcuradorGeral da República, no parecer de folhas 38 e 39, opina pelo não conhecimento da impugnação - quer pela irregularidade da representação processual, quer por versar a peça sobre matéria diversa da prevista no artigo $226, \S 2$, do Regimento Interno - e pela concessão da execução. 
2. Conforme consignado pelo Procurador-Geral da República, a peça de folhas 33 e 34 está subscrita por profissional da advocacia que não foi devidamente credenciado nos autos pelo interessado M. O. Assim, impossível é tomá-la como impugnação. No mais, inexiste óbice à execução da carta em território brasileiro, isso considerada a soberania nacional e a ordem pública. Visa o documento a cientificar o interessado de sentença proferida contra si.

3. Defiro a execução da carta. Remeta-se à Justiça Federal de São Paulo.

4. Uma vez alcançado o objeto que lhe é próprio, ou seja, a ciência da sentença por M. O., devolva-se o instrumento a esta Corte, para remessa, por via diplomática, à origem.

5. Publique-se.

Brasília, 7 de agosto de 2001.

Ministro MARCO AURÉLIO

Presidente

\title{
OUTROS
}

\author{
Classe / Origem \\ PET-1582/SP \\ PETICAO
}

\section{Relator \\ Min. CELSO DE MELLO DJ DATA-26-02-99 P-00028}

\section{Julgamento}

10/02/1999 Despacho

DECISÃO: A Justiça estadual de primeira instância encaminha, à Presidência do Supremo Tribunal Federal, carta rogatória com o objetivo de solicitar ao Juízo estrangeiro rogado a execução, em território do Japão, de diligência consistente na citação de réu em processo judicial de natureza civil. A providência ora solicitada pelo ilustre magistrado brasileiro rogante, consubstanciada em típica comissão rogatória ativa, não se inclui na esfera de atribuições jurisdicionais do Supremo Tribunal Federal, cuja competência originária, no tema, restringe-se, unicamente, às cartas rogatórias passivas, vale dizer, àquelas dirigidas pela justiça estrangeira ao Poder Judiciário do Brasil. Na verdade, somente o instrumento rogatório emanado de órgão competente da justiça estrangeira (carta rogatória passiva) reveste-se de idoneidade jurídica para expor-se ao juízo de delibação do Presidente do Supremo Tribunal Federal, para efeito de eventual concessão do exequatur. É por essa razão que a Constituição da República, ao dispor sobre as atividades de cooperação judiciária situadas no âmbito da competência internacional desta Suprema Corte, subordina o cumprimento das cartas rogatórias oriundas de autoridades estrangeiras à prévia concessão 
do exequatur pelo Presidente do S.T.F. (art. 102, I, h, segunda parte). Como se sabe, o exequatur - que traduz uma ordem de execução emanada do Supremo Tribunal Federal - somente tem pertinência, em nosso sistema de direito positivo, se se tratar de cartas rogatórias encaminhadas ao Brasil pela Justiça rogante de Estados estrangeiros. Vê-se, portanto, que a concessão do exequatur - que se inclui na esfera de competência monocrática do Presidente do Supremo Tribunal Federal, por efeito de expressa autorização constitucional (CF, art. 102, I, h, in fine) - qualifica-se como ato veiculador de determinação formal destinada a viabilizar, no Brasil, o cumprimento de certos atos de natureza processual solicitados, às autoridades judiciárias nacionais, mediante comissões rogatórias provenientes do exterior. É interessante observar que, no Brasil, as cartas rogatórias passivas eram inicialmente cumpridas sem a formalidade da prévia concessão do exequatur. Na realidade, até 1847 - data em que foi expedido, pelo Ministério da Justiça, um Aviso disciplinando o cumprimento de cartas rogatórias passivas dirigidas à Justiça do Brasil -, estas eram encaminhadas diretamente aos Juízes nacionais pelas próprias partes interessadas, sem que desse fato tivesse ciência o próprio Governo Imperial brasileiro (ARTHUR BRIGGS, "Cartas Rogatórias Internacionais", p. 07, 1913, Imprensa Nacional). PONTES DE MIRANDA ("Comentários à Constituição de 1946", vol. III/107, item n. 2, 2ª ed., 1953, Max Limonad), ao referir-se a esse período, assinalou: "Até 1847, as cartas rogatórias, inclusive executórias, eram cumpridas pelos juízes, sem qualquer formalidade processual, recebendo-as diretamente das partes. Regime de clandestinidade, se bem que limitado às cartas rogatórias de Portugal." Com a superveniência da Lei federal n²21, de 20/11/1894, o Estado brasileiro instituiu o exequatur - verdadeiro ato de caráter político-jurídico como requisito necessário ao cumprimento das comissões rogatórias encaminhadas pela Justiça estrangeira: "As rogatórias emanadas de autoridades estrangeiras serão cumpridas somente depois que obtiverem o exequatur do governo federal..." (art. 12, § 4⿻丷). O exequatur, portanto, sob a égide da Constituição republicana de 1891, achava-se incluído na esfera de competência administrativa do Governo federal, cabendo, então, ao Ministro da Justiça, a prática oficial desse ato, consoante ressalta HAROLDO VALLADÃO ("Estudos de Direito Internacional Privado", p. 530/531, 1947). Foi somente com a Constituição Federal de 1934 que a atribuição de conceder exequatur deslocou-se, da instância meramente político-administrativa, para a esfera de competência originária do Supremo Tribunal Federal: mais especificamente, para o âmbito de atuação monocrática do Presidente do Supremo Tribunal Federal (art. 77). Sabemos que há duas modalidades de cartas rogatórias. De um lado, as cartas rogatórias ativas, vale dizer, aquelas encaminhadas pelo juiz brasileiro a magistrados de outros países e, de outro, as comissões rogatórias passivas, ou seja, aquelas que são dirigidas por juízes de Estados estrangeiros à Justiça brasileira (EDUARDO ESPÍNOLA FILHO, "Código de Processo Penal Brasileiro", vol. VII/611, item n. 1588, 2ª ed., 1945, Freitas Bastos; ROBERTO LYRA, "Comentários ao Código de Processo Penal”, vol. VI/445-446, item n. 83, 1944, Forense; LUÍS CEZAR RAMOS PEREIRA, "Carta Rogatória", in Revista de Processo no 34/292, v.g.). Daí a observação feita por JOSÉ FREDERICO MARQUES ("Instituições de Direito Processual Civil", vol. II/331, item n. 504, 4⿳⺈ ed., 1971, Forense): "De duas espécies são as cartas 
rogatórias: quando enviadas do Brasil para outro país elas se denominam rogatórias ativas; quando remetidas de país estrangeiro para serem entre nós cumpridas, elas se chamam rogatórias passivas" (grifei). Vê-se, portanto, que a presente carta rogatória, dirigida por autoridade judiciária brasileira à Justiça do Japão, com a formal solicitação de prática processual a ser efetivada em território de outro País (ato de citação em processo civil), subsume-se à noção de comissão rogatória ativa, insuscetível, por isso mesmo, de ser préexaminada, em instância de mera delibação, pelo Presidente do Supremo Tribunal Federal. O Código de Processo Civil, ao disciplinar as cartas rogatórias ativas (art. 210) e as cartas rogatórias passivas (art. 211), dispõe - tratando-se de comissões rogatórias ativas - que estas obedecerão, quanto à sua admissibilidade e modo de seu cumprimento, àquilo que dispuser a convenção internacional eventualmente existente. Na falta de tratado ou acordo internacional, o instrumento rogatório ativo será remetido à autoridade judiciária estrangeira, por via diplomática, depois de traduzido para a língua do país em que houver de praticar-se o ato rogado. Constata-se, dessa maneira, que, em sede de cartas rogatórias ativas, ou seja, daquelas encaminhadas por juízes brasileiros à Justiça de outros países, o iter procedimental a elas pertinente não prevê a intervenção do Presidente do Supremo Tribunal Federal, posto que, ou deverão ser dirigidas pelos próprios magistrados nacionais ao Ministro da Justiça, que, por sua vez, encaminhá-las-á ao Ministério das Relações Exteriores do Brasil, para que o Itamaraty, então, proceda à remessa do instrumento rogatório às missões diplomáticas brasileiras situadas no exterior, ou observar-se-á a regra fixada em convenção internacional, quando existente. As missões diplomáticas brasileiras, por sua vez, submeterão as cartas rogatórias oriundas do Brasil à apreciação das autoridades competentes do Estado estrangeiro a que foram destinadas. No caso presente, trata-se de típica hipótese de carta rogatória ativa, a que não se aplica, ante as razões expostas, a disciplina normativa prevista no texto constitucional (CF, art. 102, I, h, in fine) e no Regimento Interno do S.T.F. (arts. 225/229), circunstância esta que afasta, por completo, a possibilidade jurídica de intervenção processual do Presidente do Supremo Tribunal Federal, a cujo juízo de delibação - como precedentemente já enfatizado - estão unicamente sujeitas as comissões rogatórias passivas, consoante adverte autorizado magistério doutrinário (CASTRO NUNES, "Teoria e Prática do Poder Judiciário", p. 192, item n. 9, 1943, Forense; THEMISTOCLES BRANDÃO CAVALCANTI, "A Constituição Federal Comentada", vol. II/346, 1948, Konfino; OSCAR TENÓRIO, "Direito Internacional Privado", vol. 2/370-372, itens ns. 1218/1222, 11를 ed., 1976, Freitas Bastos; EDUARDO ESPÍNOLA e EDUARDO ESPÍNOLA FILHO, "A Lei de Introdução ao Código Civil Brasileiro", vol. 3/246-247, item n. 319, 2ª ed., 1995, Renovar; MARIA HELENA DINIZ, "Lei de Introdução ao Código Civil Brasileiro Interpretada", p. 305, item n. 6, 1994, Saraiva; PONTES DE MIRANDA, "Comentários ao Código de Processo Civil”, tomo III/255, 2ª ed., 1979, Forense; PINTO FERREIRA, "Código de Processo Civil Comentado", vol. 2/10, 1996, Saraiva, v.g.). Ao contrário do que prescreve o Código de Processo Penal, que determina o prévio encaminhamento das cartas rogatórias ativas ao Ministro da Justiça (art. 783), a legislação processual civil nada dispõe especificamente quanto a esse procedimento em tema de rogatórias ativas de natureza 
Pesquisa de casos envolvendo divórcios japoneses no Supremo Tribunal Federal 213

civil. Prática consuetudinária, no entanto, tem legitimado, mesmo em sede de rogatórias ativas de natureza civil, a remessa prévia dos respectivos instrumentos ao Ministério da Justiça, não obstante seja lícito, até mesmo com fundamento no art. 210 do CPC, proceder-se ao encaminhamento direto de tais cartas ao Ministério das Relaçôes Exteriores. Desse modo, e com apoio na prática consuetudinária em referência, encaminhem-se os presentes autos ao Senhor Ministro de Estado da Justiça, a quem caberá verificar se o instrumento rogatório ativo se acha, ou não, regularmente instruído e devidamente formalizado. Deverão permanecer nos autos cópias das peças referidas, além do original do presente ato decisório. Transmita-se, ao Juízo estadual rogante ( $3^{3}$ Vara Cível da Comarca de Presidente Prudente/SP), cópia integral da presente decisão.

Publique-se.

Brasília, 10 de fevereiro de 1999.

Ministro CELSO DE MELLO

Presidente

5

Observação

Alteração: 12/06/00, (SVF).

\section{Acórdãos}

\section{HOMOLOGAÇÃO DE SENTENÇA}

1) SENTENCA ESTRANGEIRA CONTESTADA-SEC-6399/JA

Relator(a): Min. MARCO AURÉLIO

Publicação: DJ DATA-15-09-00 PP-00119 EMENT VOL-02004-01 PP-00020

\section{Julgamento: 21/06/2000 - TRIBUNAL PLENO}

Ementa

SENTENÇA ESTRANGEIRA - HOMOLOGAÇÃO - DIVÓRCIO - ATO ADMINISTRATIVO - EXTENSÃO. A norma inserta na alínea " $h$ " do inciso I do artigo 102 da Constituição Federal, segundo a qual compete ao Supremo Tribunal Federal processar e julgar, originariamente, a homologação das sentenças estrangeiras, há de ser tomada respeitando-se a soberania do país em que praticado o ato. Prevendo a respectiva legislação o divórcio mediante simples ato administrativo, como ocorre, por exemplo, no Japão, cabível é a homologação para que surta efeitos no território brasileiro. Precedentes: Sentença Estrangeira nº 1.282/Noruega, Relator Ministro Mário Guimarães; Sentença Estrangeira nº 1.312/Japão, Relator Ministro Mário Guimarães; Sentença Estrangeira nº 1.943/Dinamarca, Relator Ministro Adaucto Cardoso; Sentença Estrangeira n 2.251/Japão, Relator Ministro Moreira Alves; Sentença Estrangeira no 2.626/Bélgica, 
Presidente Ministro Antonio Neder; Sentença Estrangeira n².891/Japão, Presidente Ministro Xavier de Albuquerque; Sentenças Estrangeiras nºs 3.298, 3.371 e 3.372, todas do Japão, Presidente Ministro Cordeiro Guerra; e Sentença Estrangeira no 3.724/Japão, Presidente Ministro Moreira Alves.

Observação

Votação: Unânime.

Resultado: Homologada.

Veja : SE-1282, SE-1312, SE-1943, RTJ-43/641, SE-2251,

RTJ-77/389, SE-2626, SE-2891, SE-3298, SE-3371, SE-3372, SE-3724.

N.PP:: (09). Análise:(CMM). Revisão:(RCO/AAF).

Inclusão: 21/11/00, (SVF).

Alteração: 23/11/00, (SVF).

Legislação

LEG-FED CFD-****** ANO-1988

ART-00102 INC-00001 LET-H

Indexação

****** CF-88 CONSTITUICAO FEDERAL

IN0041, SENTENÇA ESTRANGEIRA, DIVORCIO, DECRETAÇÃO, ATO ADMINISTRATIVO, PAÍS DE ORIGEM, FORMALIDADES LEGAIS, OBSERVÂNCIA, INTERPRETAÇÃO ADITIVA

\section{2) SENTENCA ESTRANGEIRA- SE-4269 / DF}

Relator(a): Min. OCTAVIO GALLOTTI

Publicação: DJ DATA-13-09-91 PP-12489 EMENT VOL-01633-01 PP-00092 RTJ VOL-00137-02 PP-00618

\section{Julgamento: 16/08/1991 - TRIBUNAL PLENO}

Ementa

Divorcio amigável, procedente do Japão. Ausência do teor do ato administrativo que se pretende homologar, não bastando, para a homologação, perante o Supremo Tribunal Federal, a prova da sua averbação, no registro civil (artigos 218 e 219, e seu parágrafo único, do Regimento Interno). Extinção do processo com ressalva da possibilidade de renovação do pedido, instruído com o documento indispensável.

Observação

VOTACAO: UNANIME.

RESULTADO: EXTINTO O PROCESSO.

VEJA SE-1313.

N.PP: (6). REVISAO:(NCS).

ALTERACAO: 25.07.00, (MLR).

Legislação

LEG-FED RGI-****** ANO-1980 
Pesquisa de casos envolvendo divórcios japoneses no Supremo Tribunal Federal 215

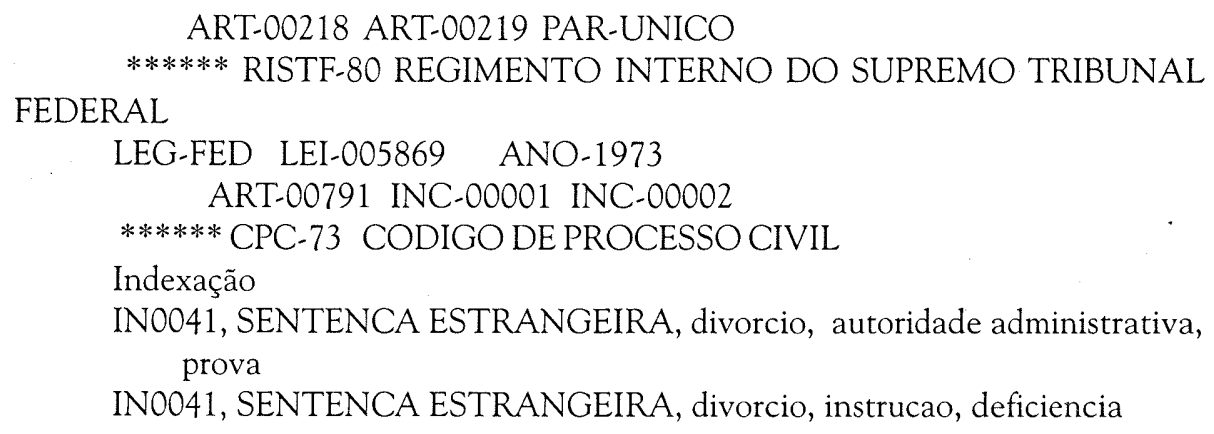

IN0041, SENTENCA ESTRANGEIRA, divorcio, autoridade administrativa, prova

IN0041, SENTENCA ESTRANGEIRA, divorcio, instrucao, deficiencia

3) SENTENCA ESTRANGEIRA .- SE-4852 / JA

Relator(a): Min. OCTAVIO GALLOTTI

Publicação: DJ DATA-27-08-93 PP-17037 SE VOL-00014-01 PP-00139

Julgamento: 18/08/1993 -

Ementa

NAO CONSTA.

Observação

RESULTADO: HOMOLOGADA.

N.PP::(1). ANALISE:(JBM). REVISAO:(NCS).

INCLUSAO : 20.05.94, (AK).

Indexação

INO041, SENTENCA ESTRANGEIRA, DIVORCIO, FILHOS, GUARDA, PARTILHA,

DIREITO, RENUNCIA

4) SENTENCA ESTRANGEIRA -- SE-3869 / JA

Relator(a): Min. RAFAEL MAYER

Publicação: DJ DATA-21-04-88 PP-08833 SE VOL-00013-01 PP-00020 RTJ VOL00125-01 PP-00072

Julgamento: $12 / 04 / 1988$ -

Ementa

DIVORCIOS CONSENSUAIS PERANTE AUTORIDADES ADMINISTRATIVAS JAPONESAS. - PRESENCA DE CONJUGE BRASILEIRO BINUBO. O SEGUNDO DIVORCIO ENTRE OS MESMOS CONJUGES NAO ELIDE A APLICACAO DO ART. 38 DA LEI 6.515/77, QUE ENTRETANTO, NAO INCIDE SOBRE O CONJUGE ESTRANGEIRO. - HOMOLOGACAO IRRESTRITA 
DO PRIMEIRO DIVORCIO, E COM RESTRICOES A HOMOLOGACAO DO SEGUNDO, QUANTO AO CONJUGE BRASILEIRO.

Observação

RESULTADO: HOMOLOGADO O 1. DIVORCIO SEM RESTRICOES E O SEGUNDO COM

RESTRICOES.

VEJA SE-3638.

N. PP.: (6). ANALISE: (JBM). REVISAO: (NCS).

IMPLANTACAO: 26.05.93, (NERLI). ALTERACAO: 03.03.94, (MK).

Legislação

LEG-FED DEL-004657 ANO-1942

ART-00007

****** LICC-42 LEI DE INTRODUCAO AO CODIGO CIVIL

LEG-FED LEI-006515 ANO-1977

ART-00033 PAR-00038

Indexação

IN0041, SENTENCA ESTRANGEIRA, DIVORCIO, AUTORIDADE ADMINISTRATIVA, CONJUGE BRASILEIRO, BINUBO

5) SENTENCA ESTRANGEIRA .- SE-3549/

Relator(a): Min. MOREIRA ALVES

Publicação: SE VOL-00010-01 PG-00095 DJ DATA-02-05-85 PG-06206

Julgamento: 22/04/1985 -

Ementa

DIVORCIO POR MUTUO CONSENTIMENTO, REGISTRADO PERANTE AUTORIDADE ADMINISTRATIVA. SISTEMA JURIDICO JAPONES. PRESENCA DE CONJUGE BRASILEIRO. HOMOLOGACAO CONCEDIDA, COM RESTRICOES.

Observação

RESULTADO: HOMOLOGADA.

ANO:85

Legislação

LEG-FED RGI-****** ANO-1980 ART-00216 ART-00217

***** RISTF-80 REGIMENTO INTERNO DO SUPREMO TRIBUNAL

FEDERAL

Indexação

DEFERIMENTO, EFEITO, SEPARACAO JUDICIAL, PEDIDO, HOMOLOGACAO,

SENTENCA JUDICIARIA ESTRANGEIRA, DIVORCIO, CONSENTIMENTO, PARTES, 
Pesquisa de casos envolvendo divórcios japoneses no Supremo Tribunal Federal 217

DECRETACAO, AUTORIDADE ADMINISTRATIVA, CONJUGE, ESTRANGEIRO, CONJUGE BRASILEIRO.

RECONHECIMENTO, COMPETENCIA, JUSTICA ESTRANGEIRA, FUNDAMENTACAO,

NACIONALIDADE, DOMICILIO, CONJUGE, ESTRANGEIRO.

IN0185,SENTENCA ESTRANGEIRA

DIVORCIO

AUTORIDADE ADMINISTRATIVA

IN0097,SENTENCA ESTRANGEIRA

DIVORCIO

EFEITO DE SEPARACAO JUDICIAL

PC0255,COMPETENCIA JURISDICIONAL, CIVEL,

SENTENCA ESTRANGEIRA

DIVORCIO

Acórdãos no mesmo sentido

PROC-SE NUM-0003550 ANO-85 UF-JA TURMA-** MIN-128

SE VOL-00010-01 PG-00096 DJ DATA-06-09-85

PG-14881

6) SENTENCA ESTRANGEIRA .- SE-2251 / JA

Relator(a): Min. MOREIRA ALVES

Publicação: DJ DATA-27-02-76 PG-01281 EMENT VOL-01013-01 PG-00007 RTJ VOL-00077-02 PG-00389

\section{Julgamento: 15/10/1975 - TRIBUNAL PLENO}

Indexação da Revista Trimestral do STF

INT , SENTENCA ESTRANGEIRA, DIVORCIO NO JAPAO, CONJUGE BRASILEIRO,

HOMOLOGACAO COM RESTRICOES

Ementa

DIVORCIO. E HOMOLOGAVEL NO BRASIL DIVORCIO POR MUTUO CONSENTIMENTO QUE, SEGUNDO O SISTEMA JURIDICO JAPONES, SE REGISTRA PERANTE AUTORIDADE ADMINISTRATIVA, INDEPENDENTEMENTE DE MANIFESTACAO JUDICIAL. PRECEDENTE DO S.T.F. HOMOLOGACAO COM RESTRICOES, EM FACE DA NACIONALIDADE BRASILEIRA DE UMA DAS PARTES.

Observação

VOTACAO: UNANIME. RESULTADO: HOMOLOGADA COM RESTRICOES.

REC 5PP.

ANO:76 AUD:25-02-76 
ALTERACAO: 25.03.96, (NT).

Legislação

LEG-FED EMC-000001 ANO-1969 ART-00101 INC-00001

***** CF-69 CONSTITUICAO FEDERAL

LEG-FED DEL-004657 ANO-1942 ART-00007 PAR-00006

***** LICC-42 LEI DE INTRODUCAO AO CODIGO CIVIL

Indexação

IN0185,SENTENCA ESTRANGEIRA

DIVORCIO

AUTORIDADE ADMINISTRATIVA

Acórdãos no mesmo sentido

PRECEDENTE $(S)$

16-09-53

PROC-SE NUM-0001312 ANO-53 UF-JA TURMA-TP MIN-100 AUD-

DJ DATA-17-09-53 PG-11266 EMENT VOL-00143-01 PG-00018

\section{OUTROS}

SENTENCA ESTRANGEIRA .- SE-2446/

Relator(a): Min. ANTONIO NEDER

Publicação: SE VOL-00003-01 PG-00074 DJ DATA-17-12-79 PG-09507 RTJ VOL00092-02 PG-00522

Julgamento: 19/11/1979 .

Ementa

1. SENTENCA PARAGUAIA DE DIVORCIO. CASO EM QUE O VARAOE JAPONES DOMICILIADO NO BRASIL, E A MULHER, JAPONESA, TEM DOMICILIO CERTO E SABIDO NESTE PAIS, E EM CUJO PROCESSO FOI ELA CITADA POR EDITAL. NULA E A CITACAO FICTA NA ESPECIE E, PORTANTO, NULO E O PROCESSO EM QUE SE PROFERIU, NO PARAGUAI, A SENTENCA QUE SE PRETENDE HOMOLOGAR. REG. INTERNO DO STF, ART. 212, II. 2. SENTENCA DE PARTILHA PROFERIDA EM PROCESSO DE DIVORCIO JULGADO NO PARAGUAI. BENS QUE SE ACHAM SITUADOS NO BRASIL. COMPETENCIA DO JUIZ BRASILEIRO, ABSOLUTA E, PORTANTO, IMPRORROGAVEL. LEI DE INTRODUCAO AO CODIGO CIVIL BRASILEIRO, ART. 12, PARAGRAFO 1. CODIGO CIVIL BRASILEIRO, ART. 44, III. CODIGO DE PROCESSO CIVIL, ARTIGO 89, II, E ART. 1.121, PARAGRAFOUNICO. LEIN. 6.515 DE 26.12.77, ART. 7., PARAGRAFO 2., ART. 31 E ART. 43. DOUTRINA BRASILEIRA SOBRE A MATERIA. INADMISSIVEL, NO BRASIL, A HOMOLOGACAO DE TAL SENTENCA ESTRANGEIRA. 3. SENTENCA ESTRANGEIRA QUE JULGOU 
Pesquisa de casos envolvendo divórcios japoneses no Supremo Tribunal Federal 219

JUSTIFICACAO DE CERTO FATO PARA SERVIR DE PROVA EM PROCESSO DE ACAO HOMOLOGATORIA DE SENTENCA, TAMBEM ESTRANGEIRA, DE DIVORCIO. SE ESTA NAO PODE SER HOMOLOGADA, NAO SE JUSTIFICA A HOMOLOGACAO DA OUTRA QUE LHE COMPLEMENTA O CONTEUDO. 4. ACAO HOMOLOGATORIA IMPROCEDENTE.

Observação

RESULTADO: IMPROCEDENTE.

VEJA SE-2289, SE-2293, SE-2151

ANO:79

Legislação

LEG-FED DEL-004657 ANO-1942 ART-00044 INC-00003 ART-01775 ART-01777 ART-01779

***** LICC-42 LEI DE INTRODUCAO AO CODIGO CIVIL

LEG-FED LEI-005869 ANO-1973 ART-00084 INC-00002 ART-00089

INC-00002 . ART-01121 PAR-UNICO

***** CPC-73 CODIGO DE PROCESSO CIVIL

LEG-FED LEI-006515 ANO-1977 ART-00007 PAR-00002 ART-00031

ART-00043

LEG-FED RGI-****** ANO-1970 ART-00211 INC-00002 ART-00212

***** RISTF-70 REGIMENTO INTERNO DO SUPREMO TRIBUNAL

FEDERAL

Indexação

INDEFERIMENTO, PEDIDO, HOMOLOGACAO, SENTENCA JUDICIARIA

ESTRANGEIRA, DIVORCIO, CONJUGE, ESTRANGEIRO, DOMICILIO, BRASIL,

NULIDADE, CITACAO, REQUERIDO.

INDEFERIMENTO, PEDIDO, HOMOLOGACAO, SENTENCA JUDICIARIA

ESTRANGEIRA, COMPROVACAO, IDENTIDADE, REQUERENTE, DIVORCIO.

INDEFERIMENTO, PEDIDO, HOMOLOGACAO, SENTENCA JUDICIARIA ESTRANGEIRA, PARTILHA, IMOVEL, LOCALIZACAO, BRASIL, INCOMPETENCIA,

JUIZO, ESTRANGEIRO.

IN0187,SENTENCA ESTRANGEIRA

DIVORCIO

CITACAO POR EDITAL ,NULIDADE,

INO188,SENTENCA ESTRANGEIRA

DIVORCIO

PARTILHA DE BENS - INCOMPETENCIA DO JUIZO 

